\title{
Magnitude, frequency and hazard assessment of the largest floods in steep, mountainous bedrock channels of the Southern Judean Desert, Israel
}

\author{
Rami Zituni $^{\mathrm{a}, *}$, Noam Greenbaum ${ }^{\mathrm{a}}$, Naomi Porat ${ }^{\mathrm{b}}$, Gerardo Benito ${ }^{\mathrm{c}}$ \\ ${ }^{\text {a }}$ University of Haifa, 199 Aba Khoushy Ave., Haifa, 3498838, Israel \\ ${ }^{\mathrm{b}}$ Geological Survey of Israel, 32 Yesha'ayahu Leibowitz St., Jerusalem, 9692100, Israel \\ ${ }^{\mathrm{c}}$ Department of Geology, National Museum of Natural Sciences (MNCN), CSIC, Serrano 115 bis, 28006, Madrid, Spain
}

\section{A R T I C L E I N F O}

\section{Keywords:}

Palaeoflood hydrology

Judean Desert Israel

Steep ephemeral streams

Floods magnitude

Flood frequency analysis

Hazard assessment

\begin{abstract}
A B S T R A C T
Study region: Southern Judean Desert, Israel.

Study focus: To extend the flood record in two basins in the Judean Desert for facilitating the quality and reliability of the flood frequency analysis (FFA).

New hydrological insights for the region: The hydrological data for The Judean Desert streams is partial to none. This study applied palaeoflood hydrology method, which analyzes sedimentological evidence of past large floods in two streams. One basin (N. Ze'elim, $250 \mathrm{~km}^{2}$ ) yield maximum palaeo-discharge of $900 \mathrm{~m}^{3} \mathrm{~s}^{-1}$ and the other (N. Rahaf, $\left.55 \mathrm{~km}^{2}\right) 1250 \mathrm{~m}^{3} \mathrm{~s}^{-1}(1.3$ and 2.3 times larger than the maximum measured floods, respectively), for records of 500 and 5000 years, respectively. Combining these data with measured and historical data produced a palaeohydrological data-base of several hundred to thousands years long. These data updated the regional envelope curves for the maximum peak discharges. The improved FFA caused a decrease for the 100-year flood in the larger basin, from $1750 \mathrm{~m}^{3} \mathrm{~s}^{-1}$, for the systematic record only, to 760 $\mathrm{m}^{3} \mathrm{~s}^{-1}(43 \%)$ for the combined records, and from $1260 \mathrm{~m}^{3} \mathrm{~s}^{-1}$ to $980 \mathrm{~m}^{3} \mathrm{~s}^{-1}$, in the other basin $(77$ $\%)$. The FFA for the systematic + historic data only, overestimated the frequency of the large floods due to their short and discontinuous records. The extension of the record with the palaeoflood data reduced the peak discharge values for different return periods and significantly enhanced FFA reliability.
\end{abstract}

\section{Introduction}

Dryland environments occupy $40 \%$ of the land area supporting nearly $30 \%$ of the world's population mostly in developing countries (UNEP, 2011). One of the main characteristics of dryland rivers is their flashy ephemeral flow (Schick, 1988; Bull and Kirkby, 2002), unless they have a source outside the dryland area. As these flows are scarce and rarely measured, there are few data from which to assess the long-term frequency of flood events, that is crucial for flood hazard assessment. A recent review by Metzger et al. (2020) describes the challenges in generating flood frequency analysis for sites in arid/semiarid regions, highlighting the large errors in conventional use of extreme value theory methods in watersheds with a limited number of floods per year and large variability of flood peak discharges. Regional flood-frequency relations based on dimensionless frequency curves derived from all available annual peak

\footnotetext{
* Corresponding author.

E-mail address: ramizituni@gmail.com (R. Zituni).
} 
discharge data within homogeneous regions also provide unsatisfactory results due to the weight of rare floods on the distribution tails and the spatially heterogeneous flood hydrology (Farquharson et al., 1992; Zaman et al., 2012).

The present study uses palaeoflood hydrology to reconstruct past, undocumented floods along the Judean desert streams. The evidence of past floods has accumulated along the stream channels and in the tributaries, for hundreds and thousands of years (Kochel and Baker, 1982; Baker and Kochel, 1988), providing long-term records for ungauged basins, and/or extending measured flood records. The largest flood to have occurred within a basin can serve as a control on envelope curves and rainfall-runoff models such as Probable Maximum Precipitation-Probable Maximum Flood (PMP-PMF). Palaeoflood records enhance the frequency analyses of flood records by improving the fit of the probability functions and also serve as a control vis a vis other statistical estimates (Webb et al., 1988). Combining the palaeoflood information with measured and historical data, provides a long hydrological database, which can help to improve flood risk assessment for ungauged basins, or with limited data, typical of arid environments (Stedinger and Cohn, 1986; Frances et al., 1994; Benito and Thorndycraft, 2005).

Palaeoflood studies aimed at extending flood records and improving flood frequency analyses, began in the 1970s in the U.S. (e.g., Patton et al., 1979; Kochel et al., 1982; Ely and Baker, 1985; Baker, 1987; Webb et al., 1988; Patton et al., 1993; Enzel et al., 1993; O'Connor, 1994; Webb et al., 2002), and were later conducted worldwide (e.g., Baker, 1987; Ely et al., 1993; Kale et al., 2000; Greenbaum et al., 2001; Sheffer et al., 2003; Benito et al., 2003a, 2003b; Greenbaum et al., 2006; Benito et al., 2011; Grodek et al., 2013; Greenbaum et al., 2014b; Hu et al., 2016; Cloete et al., 2018). Palaeo peak discharges and historical floods are usually higher than gauged peak discharges (Greenbaum et al., 2006; 2014a; and references therein). In the Colorado River tributaries, when the historical and palaeoflood data were combined to the systematic data, the peak discharge for the probability of predicted flood increased (Webb et al., 1988; Enzel et al., 1993, 1994). In the Upper Colorado River, a palaeoflood record exceeding 2000 years (Greenbaum et al., 2014a) showed that: (1) large floods were far more frequent than can be estimated by extrapolation from the gauged record alone, and (2) The average occurrence of large, rare floods is not adequately represented in the 100-year gauged record, which is biased towards low flows. Similar results and trends were obtained for the Green River, the largest tributary of the Colorado River (Liu et al., 2020a, 2020b).

In the Negev Desert in Israel, palaeoflood records were reconstructed for the larger ephemeral streams $\left(>1000 \mathrm{~km}^{2}\right)(\mathrm{Greenbaum}$ et al., 2001, 2006; Table 1). Systematic records for these streams exist since the 1950's (about 70 years). The palaeoflood records include some 30 reconstructed palaeofloods, which were 2-3 times greater than the measured peak discharges, during the past thousands of years. The combination of palaeoflood data and gauged records in the Negev streams has significantly improved frequency analysis reliability (Greenbaum et al., 2001; 2006).

The Judean Desert, located along the eastern flanks of the Judea mountains, in Israel, is a distinctive hydrological region (Shentsis et al., 1997), characterized by short, steep ephemeral bedrock streams ( $<250 \mathrm{~km}^{2}$ ) (Nir, 1989; Greenbaum et al., 2006). These streams, (Fig. 1) are characterized by short, partial or no hydrological data (Shentsis et al., 1997), for which estimates of magnitude and frequency of floods, are poor.

Previous hydrological studies in the southern Judean desert, oriented to flood hazard assessment, were initiated by the Dead Sea Works (DSW) - the potash producer, for two streams N. Ashalim and N. Heimar, (Fig. 1, Table 1). These streams drain directly into the southern basin of the Dead Sea and into the evaporation ponds and caused large damages in the past (Greenbaum et al., 2001; Greenbaum, 2007).

This paper presents recent advances in the use of palaeoflood data in desert environments in order to improve our understanding of flood hazards in regions with scarce hydrological monitoring. The study focuses on two short, steep bedrock streams in the southern Judean desert, for which short and partial hydrological data is available: Nahal Ze'elim (N. Ze'elim; 250 km²) and Nahal Rahaf (N. Rahaf; $77 \mathrm{~km}^{2}$ ) (Fig. 1).

Here, we (a) extend the limited hydrological data for N. Ze'elim and N. Rahaf by constructing palaeohydrological databases, and (b) analyze their combined measured and palaeoflood records to reconstruct a reliable flood frequency for the low-probability large and extreme floods.

\section{Study area - the Judean Desert}

The Judean Desert is located on the eastern flank of the Judean anticline, which is the north-south mountainous backbone ridge of Israel, at the transition from the Judean Mountains ( $<1000 \mathrm{~m}$ asl) to the Jordan Valley and Dead Sea ( $430 \mathrm{~m}$ bsl) - a distance of $\sim 25$

Table 1

Palaeohydrological data for the Negev and southern Judean deserts (after Greenbaum et al., 2006).

\begin{tabular}{llllll}
\hline $\begin{array}{l}\text { Name of } \\
\text { basin }\end{array}$ & $\begin{array}{l}\text { Drainage area } \\
\left(\mathrm{km}^{2}\right)\end{array}$ & $\begin{array}{l}\text { Maximum palaeoflood } \\
\text { discharge }\left(\mathrm{m}^{3} \mathrm{~s}^{-1}\right)\end{array}$ & $\begin{array}{l}\text { Maximum measured } \\
\text { discharge }\left(\mathrm{m}^{3} \mathrm{~s}^{-1}\right)\end{array}$ & $\begin{array}{l}\text { Number of } \\
\text { palaeofloods }\end{array}$ & $\begin{array}{l}\text { Duration of palaeoflood } \\
\text { record (years) }\end{array}$ \\
\hline $\begin{array}{l}\text { Negev Desert } \\
\text { Paran }\end{array}$ & 3600 & $2500(2950)$ & 1150 & 28 & 470 \\
Neqarot & 1000 & $2400(700)$ & $1000(700)$ & 28 & 570 \\
Zin & 1400 & $1500(1150)$ & 1300 & 27 & 2000 \\
Southern Judean Desert & & & 20 & 7600 \\
Ashalim & 75 & $400(35)$ & 420 & 22 & 300 \\
Heimar & 450 & 1100 & 538 & &
\end{tabular}

(1150) - Measured drainage area for study site $\left(\mathrm{km}^{2}\right)$. 


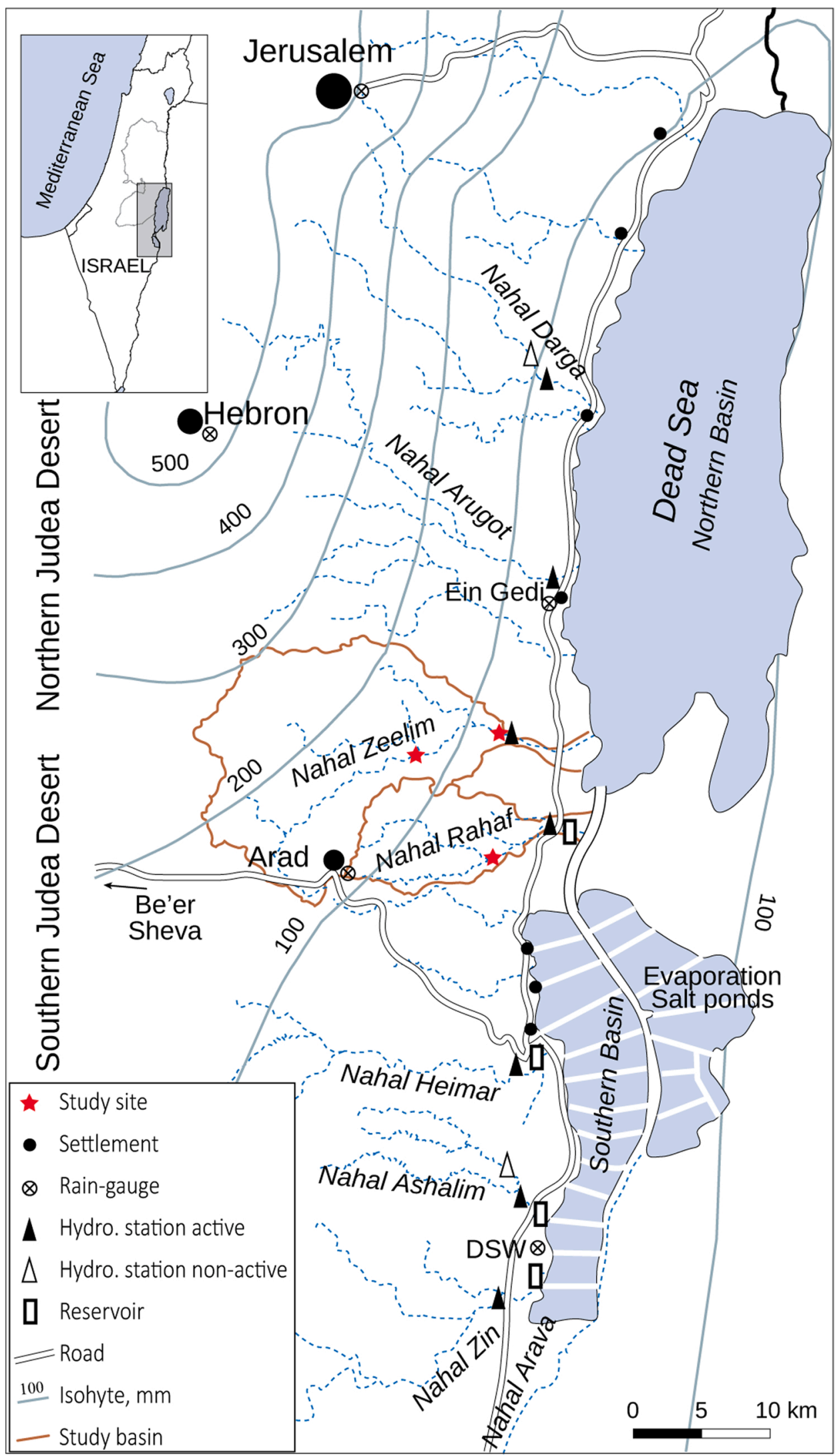


Fig. 1. (a) Location of the study area within the Dead Sea Rift valley. (b) The Judea rain-shadow Desert west of the Dead Sea including the larger

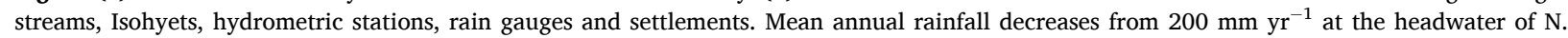
Ze'elim and N. Rahaf study basins (delimited in brown) to $50 \mathrm{~mm} \mathrm{yr}^{-1}$ at the outlet to the Dead Sea.

km (Fig. 1) with an average slope of about 4\%. The exposed rocks are mainly carbonate rocks, where the upper part consists of softer chalk and marls with some limestone and flint beds of the Mt. Scopus Group. The lower part consists of hard Upper Cretaceous limestone and dolomite of the Judean Group, incised by deep, narrow bedrock canyons.

The infrastructure is concentrated along the elongated coastline of the Dead Sea (Fig. 1), which is retreating due to the falling level of the lake at an average rate of $1 \mathrm{~m} \mathrm{yr}^{-1}$. The retreating coast is actively cut by numerous, steep, west-east ephemeral streams of the Judean Desert (Fig. 1).

\subsection{Climate}

The Judean Desert is an extension of the desert fringe of the Sinai and Negev, which, due to its low topography and the rain-shadow effect extends northward into the Dead Sea Valley. The average annual rainfall in the Judean Desert declines from north to south and from west to east. In the northern more humid part, the mean annual rainfall decreases from 500 to $400 \mathrm{~mm} \mathrm{yr}^{-1}$ at the top of the Judean Mountains to $50 \mathrm{~mm} \mathrm{yr}^{-1}$ along the Dead Sea. In the more arid, southern Judean Desert, the mean annual rainfall at the water divide, ranges from 250 to $100 \mathrm{~mm} \mathrm{yr}^{-1}$ (Fig. 1). The rainfall along the Dead Sea decreases from $148 \mathrm{~mm} \mathrm{yr}^{-1}$ in Jericho (north) to 46 $\mathrm{mm} \mathrm{yr}^{-1}$ in Sedom (south) (Israel National Atlas, 2011). Most of the annual precipitation in the Judean Desert and Dead Sea area (50-100 $\mathrm{mm} \mathrm{yr}^{-1}$ ) falls in relatively short rainstorms in the autumn and spring months (October-November and March-April).

The climate regime of the Judean Desert is affected by three distinct circulation patterns (Dayan and Morin, 2006; Armon et al., 2018): (1) Mediterranean Cyclones (MC) — the most active cold fronts of the Mediterranean Sea, which are accompanied by heavy rainfall of hours to days in winter, and may extend eastward over the northwestern Judean Desert (Dayan and Morin, 2006); (2) Active Red Sea trough (ARST) - the synoptic system responsible for most of the flash floods in the southern Dead Sea (Shentsis et al., 2012). This trough, which extends from eastern equatorial Africa northward along the Red Sea into the southern and eastern regions of Israel, creates barometric conditions that encourage the development of strong, but limited convective rainstorms, marked by short duration, but high rainfall intensity, mainly during autumn and spring (Greenbaum et al., 1998, 2006; Dayan and Morin, 2006); (3) Tropical Plumes (TP) _elongated bands of upper- and mid-level clouds stretching from the tropics pole-wards and eastwards into the subtropics, typically accompanied by a subtropical jet (STJ) streak and a trough on their poleward side (Knippertz, 2005). TP systems account for $\sim 8 \%$ of the large floods in the Negev and usually produce relatively widespread and prolonged rainfall (Kahana et al., 2002; Armon et al., 2018).

The combination of these climatic systems in the streams of the Judean Desert results in rainstorms and flows that occur mainly in autumn and spring and to a lesser extent, during winter, but potentially the flood season can last for nine months (September to May).

\subsection{Streams of the southern Judean Desert}

\subsubsection{Nahal Ze'elim}

N. Ze'elim is an ephemeral stream $\left(250 \mathrm{~km}^{2}\right)$ and the second largest basin in the Judean Desert (Fig. 1). The lower $8 \mathrm{~km} \mathrm{long} \mathrm{reach}$ of the stream until its outlet to the Dead Sea, is entrenched into the resistant carbonate rocks to form a large bedrock canyon. Our study reach is located at the lower segment of this canyon, where the stream crosses the N-S escarpment of the western fault system of the Dead Sea Rift. Downstream, the channel opens to form a large alluvial fan (Amit and Gerson, 1986; Levran, 2018). Mean annual rainfall decreases from $\sim 250 \mathrm{~mm} \mathrm{yr}^{-1}$ at the headwaters to $\sim 50 \mathrm{~mm} \mathrm{yr}^{-1}$ at the outlet. Hydrological data from the past 4 years only were collected from a new (2016) hydrometric station close to the outlet (Table 4).

\subsubsection{Nahal Rahaf}

N. Rahaf $\left(77 \mathrm{~km}^{2}\right)$ drains an arid region of the southern Judean Desert (Fig. 1). Most of the exposed bedrock within the basin composed of the resistant carbonate rocks and therefore, most of the channel is in the form of a narrow bedrock canyon, separated into two segments by a structural-sourced, short $(\sim 1 \mathrm{~km})$ alluvial segment. Mean annual rainfall decreases from about $130 \mathrm{~mm}$ yr ${ }^{-1}$ at its headwater near the town of Arad to about $50 \mathrm{~mm} \mathrm{yr}^{-1}$ at the outlet to the Dead Sea.

At its outlet, the basin drains into an artificial reservoir $\left(3 \times 10^{6} \mathrm{~m}^{3}\right)$, constructed by the DSW in order to prevent water and sediments (Cohen and Laronne, 2005) from entering the evaporation ponds. Hydrological data has been collected since 1991 from a hydrometric station close to the outlet operated by the Israel Hydrological Service (IHS). The study site is located at the outlet of the upper canyon (Fig. 1), where the drainage area is $\sim 50 \mathrm{~km}^{2}$.

\section{Methods}

\subsection{Palaeoflood hydrology}

Palaeoflood hydrology is optimally applied in narrow bedrock canyons in which the water stage is high during large floods, peak palaeo stage indicators (PSIs) are preserved for a long time (Baker, 1987; Webb et al., 2002; Greenbaum et al., 2006) and also scour or 
sedimentation along the channel, is limited. The common PSIs in the Negev and Judean Desert streams include: (a) Slack Water Deposits (SWD) - fine-grained sediments transported as suspended sediments during floods and rapidly deposited during the high stage of the flood in sheltered sites where the flow energy is dramatically reduced, (b) organic layers (Baker and Kochel, 1988; Webb et al., 2002), located at the same sites as the SWDs or in the form of driftwood lines along the canyon walls. In this study, the stratigraphic sequences of the SWD's were separated into individual flood events using the well-established sedimentological criteria (Baker, 1987; Benito et al., 2003b).

\subsection{Dating methods}

To ascertain the age of the floods and thence clarify the field relations, dating was performed after determining the stratigraphy of the site and the field relations between the various SWD sequences.

\subsubsection{Radiocarbon}

Radiocarbon dating is the standard dating method for studies of palaeofloods (Benito and Thorndycraft, 2005). Dating material included fine woody debris and charcoal, found within the sedimentary units or as driftwood. All radiocarbon samples were analyzed at the AMS laboratory of the University of Arizona (Table 2). The radiocarbon ages were calibrated using OxCal v 4.3.2 (Ramsey, 2017) based on IntCal 20 (Reimer, 2020) calibration dataset (Table 2).

\subsubsection{Optically stimulated luminescence (OSL)}

Optically stimulated luminescence (OSL) dates the last exposure of quartz grains transported by the flood to sunlight and provides an age estimate for the flood. The OSL samples were analyzed at the Luminescence dating laboratory of the Israel Geological Survey in Jerusalem.

Samples for OSL dating were collected from SWD sedimentary units $>10 \mathrm{~cm}$ thick in order to prevent the mixing of sediments from more than one unit.

Quartz grains in the size range of 90-125 $\mu \mathrm{m}$ were extracted using routine laboratory methods (Faershtein et al., 2016). The detailed laboratory procedure is provided by Porat et al. (2015) and Faershtein et al. (2016). The purified quartz was mounted on a Ris $\varnothing$ TL/OSL reader and the equivalent dose (De) values were measured using the OSL signal and the single aliquot regenerative dose (SAR) protocol (Murray and Wintle, 2000). Preliminary measurements showed a large scatter of De values, indicating partial bleaching of the quartz grains due to insufficient exposure to daylight to reset the luminescence signal during transport (Medialdea et al., 2014). We therefore measured 1-mm aliquots, with about 50 grains each, to accentuate the scatter and allow the selection of the youngest component, which might be more representative of the best bleached grains.

Dose rates were calculated from the concentration of the radioactive elements, measured by ICP-MS (for U and Th) or ICP-OES (for $\mathrm{K})$. Cosmic dose rates were evaluated from current burial depths and the moisture content was estimated at $2 \pm 1 \%$, as appropriate for this hyper-arid region (Table 3 ).

\subsection{Hydraulic methods - HECRAS}

Palaeoflood discharge estimates follow the assumption that the height of the palaeostage evidence (high water marks) indicates, at a close range, the maximum stage reached by an identified flood ( ${ }^{\prime}$ 'Connor and Webb, 1988). The discharge estimate associated with the elevation of the slackwater flood deposits was calculated using the computer program HEC-RAS (Hydrologic Engineering Center, 2010). This one-dimensional hydraulic model software is commonly used for reconstructing water surface profiles of floods in narrow bedrock canyons with almost no floodplain and high stages.

The program uses the step-backwater method to generate water surface profiles for various discharges, iterated along the channel profile. Comparison of the elevation of the documented PSIs to the elevation of the HEC-RAS water surface profiles gives a good estimate of the minimum discharge value (O'Connor and Webb, 1988).

For sites that are located at curvatures where water surfaces are super-elevated we corrected the elevations using two formulas:

Table 2

Radiocarbon dates for Nahal Ze'elim and Nahal Rahaf palaeofloods.

\begin{tabular}{llll}
\hline Lab \# & Sample ID & Dated Material & C $^{14}$ age Years BP \\
\hline Nahal Ze'elim & & & Calibrated Age (95 \%) Years CE \\
X32925R & ZEL-11-2 & wood & post-bomb \\
X32924 & ZEL-12-1 & wood & post-bomb \\
X33872 & ZE-13-3 & charcoal & $189 \pm 21$ \\
X33873 & ZE-14 & Wood & post-bomb \\
Nahal Rahaf & & & $374 \pm 22$ \\
X32926 & RAF-U-1 & wood & $1956-2007$ CE \\
X33619 & RAF-G-2 & charcoal & $27,710 \pm 250$ \\
X34538 & RAF-G-5 & wood & $153 \pm 20$ \\
X34741 & RAF-G-BOR-1 & wood & $4267 \pm 22$ \\
X34742 & RAF-G-BOR-3 & wood & $2190 \pm 21$ \\
\hline
\end{tabular}


Table 3

OSL ages for Nahal Ze'elim and Nahal Rahaf palaeofloods.

\begin{tabular}{|c|c|c|c|c|c|c|c|c|}
\hline Lab Code & Location site-unit & Depth (m) & Dose Rate $(\mu \mathrm{Gy} / \mathrm{a})$ & No. Aliquots & OD (\%) & De (Gy) & Age (ky) & Youngest Age (ky) \\
\hline \multicolumn{9}{|c|}{ Nahal Ze'elim } \\
\hline ZEL-25 & ZE-11-6 & 0.1 & $1938 \pm 69$ & $18 / 19$ & 82 & $0.8 \pm 0.2$ & $0.4 \pm 0.1$ & \\
\hline ZEL-26 & ZE-9-1-1 & 0.25 & $1954 \pm 74$ & $14 / 19$ & 88 & $2.1 \pm 1.0$ & $1.0 \pm 0.5$ & $0.4(\mathrm{~N}=2)$ \\
\hline ZEL-27 & ZE-9-2-6 & 0.3 & $1777 \pm 58$ & $13 / 19$ & 95 & $2.3 \pm 1.5$ & $1.3 \pm 0.9$ & $0.5(\mathrm{~N}=5)$ \\
\hline \multicolumn{9}{|c|}{ Nahal Rahaf } \\
\hline RAF-1 & RAF-U-1 & 0.65 & $2307 \pm 92$ & $17 / 18$ & 20 & $17 \pm 3$ & $7.3 \pm 1.3$ & \\
\hline RAF-5 & RAF-G-4 & 0.35 & $2543 \pm 85$ & $19 / 19$ & 27 & $57 \pm 16$ & $22 \pm 6$ & \\
\hline RAF-7 & RAF-B-1 & 0.15 & $2506 \pm 96$ & $15 / 19$ & 69 & $2.3 \pm 0.7$ & $0.9 \pm 0.3$ & $0.7(\mathrm{~N}=9)$ \\
\hline
\end{tabular}

Age - ky before 2018.

Methods:

90-125 $\mu \mathrm{m}$ quartz was purified by wet-sieving to the selected grain size, dissolving carbonates by $8 \% \mathrm{HCl}$, removing heavy minerals and most feldspars by magnetic separation, and dissolving the remaining feldspars and etching the quartz with $40 \% \mathrm{HF}$ (for 40 min), followed by soaking in 16 $\% \mathrm{HCl}$ overnight to dissolve any fluorides which may have precipitated.

Samples were measured using a preheat of $10 \mathrm{~s} @ 260{ }^{\circ} \mathrm{C}$, a test dose of $\sim 4.6 \mathrm{~Gy}$ and a test dose preheat of $5 \mathrm{~s} @ 200{ }^{\circ} \mathrm{C}$. De was measured on 1 mm aliquots using a modified single aliquot regenerative (SAR) protocol. All samples show recycling ratios within $8 \%$ of 1.0 for most aliquots and negligible IR depletion ratios.

The average De and errors were calculated using unweighted mean. For samples for which more than 40 aliquots were measured, De valuse were also calculated using the Finite Mixture Model, which isolates different De components in the data.

Alpha, beta and gamma dose rates were calculated from the radioactive elements measured by ICP MS (U\&Th) or ICP-OES (K). Cosmic dose rates were estimated from the current burial depths.

OD - Overdispersion. Aliquots used - the number of aliquots used for the average De out of the aliquots measured. Youngest age was calculated from $\mathrm{N}$ youngest aliquots.

Table 4

Palaeoflood data and flood record of Nahal Ze'elim.

\begin{tabular}{|c|c|c|c|c|}
\hline Flood no. & Site & Peak Discharge $\left(\mathrm{m}^{3} \mathrm{~s}^{-1}\right)$ & Age & Source/type of data \\
\hline 1 & $\mathrm{HS}^{\mathrm{b}}$ & 680 & *Oct. 1997 & *SERS \\
\hline 2 & $\mathrm{HS}^{\mathrm{b}}$ & 400 & *Oct. 2000 & *SERS \\
\hline 3 & $\mathrm{HS}^{\mathrm{a}}$ & 380 & *April 2018 & *IHS \\
\hline 4 & $\mathrm{HS}^{\mathrm{b}}$ & 100 & * Oct. 2004 & *SERS \\
\hline 5 & ZE-14 & 900 & $* * 1980-1982 \mathrm{cal}$ CE $83 \%$ & ${ }^{\mathrm{P}} \mathrm{SWD}, \mathrm{DWL}$ \\
\hline 6 & ZE-12-3 & 620 & & ${ }^{\mathrm{P}} \mathrm{SWD}$ \\
\hline 7 & ZE-12-2 & 510 & & ${ }^{\text {PSWD }}$ \\
\hline 8 & ZE-9-1-3 & 500 & & ${ }^{\mathrm{p}} \mathrm{SWD}+\mathrm{DWL}$ \\
\hline 9 & ZE-9-1-2 & 470 & & ${ }^{\mathrm{P}} \mathrm{SWD}$ \\
\hline 10 & ZE-12-1 & 470 & $* * 2003-2007 \mathrm{cal} \mathrm{CE} 83.7 \%$ & ${ }^{\mathrm{p}} \mathrm{SWD}, \mathrm{DWL}$ \\
\hline 11 & ZE-11-6 & 450 & ${ }^{\#} 0.4 \mathrm{ky}$ & ${ }^{\mathrm{p}} \mathrm{SWD}+\mathrm{DWL}$ \\
\hline 12 & ZE-9-1-1 & 430 & ${ }^{\#} 0.4 \mathrm{ky}$ & ${ }^{\mathrm{p}} \mathrm{SWD}$ \\
\hline 13 & ZE-9-2-6 & 380 & ${ }^{\#} 0.5 \mathrm{ky}$ & ${ }^{\mathrm{P}} \mathrm{SWD}$ \\
\hline 14 & ZE-11-5 & 350 & & PSWD \\
\hline 15 & ZE-13-3 & 340 & **1661-Present cal CE (1734-1807 cal CE 53.6\%) & ${ }^{\mathrm{p}} \mathrm{SWD}, \mathrm{DWL}$ \\
\hline 16 & ZE-13-2 & 320 & & ${ }^{\mathrm{P}} \mathrm{SWD}$ \\
\hline 17 & ZE-9-2-5 & 300 & & ${ }^{\mathrm{P}} \mathrm{SWD}$ \\
\hline 18 & ZE-13-1 & 300 & & ${ }^{\mathrm{P}} \mathrm{SWD}$ \\
\hline 19 & ZE-11-4 & 270 & & ${ }^{\mathrm{P}} \mathrm{SWD}$ \\
\hline 20 & ZE-11-3 & 260 & & ${ }^{\mathrm{P}} \mathrm{SWD}$ \\
\hline 21 & ZE-9-2-4 & 250 & & ${ }^{\mathrm{P}} \mathrm{SWD}$ \\
\hline 22 & ZE-11-2 & 220 & **1959-1985 cal CE (1959-1961 cal CE 48.3\%) (1983-1985 cal CE 47.1\%) & PSWD, DWL \\
\hline
\end{tabular}

${ }^{\mathrm{a}}$ Hydrometric station of the Israel Hydrological Service (IHS) located at the outlet of the stream $\left(246 \mathrm{~km}^{2}\right)$, active since 2016.

b Soil Erosion Research Station (SERS) - historical observed floods ${ }^{\mathrm{P}}$ Palaeoflood; SWD - slackwater deposit; DWL - driftwood line.

* Measured flood.

${ }^{* * *}{ }^{14} \mathrm{C}$ age.

\# OSL age (ky before 2018).

\section{(a) Chow (1973):}

$$
Z=\frac{V^{2} B}{g R}
$$

Where: $\mathbf{Z}$ - the difference in elevation between the low side and the super-elevated side; $\mathbf{V}$ - velocity; $\mathbf{B}$ - flow width; $\mathbf{g}$ - gravity; Rradius of curvature 
(b) Federal Highway Administration (Federal Highway Administration (FHWA, 2012):

$$
\mathrm{H}_{\mathrm{b}}=\frac{k b V^{2}}{2 g}
$$

Where: $\mathbf{H}_{\mathbf{b}}$ - head losses; $\mathbf{K}_{\mathbf{b}}$ - Loss coefficients for bends; $\mathbf{V}$ - velocity; $\mathbf{g}$ - gravity

Cross-sections along our study reaches were surveyed at relatively short distances of between 20 and $100 \mathrm{~m}$ according to changes in channel geometry.

\subsection{Flood frequency analysis (FFA)}

Palaeohydrological studies provide information regarding the occurrence and magnitude of real large floods. New developments in frequency analysis allow combining non-standard data (e.g. palaeoflood or isolated historical observations) together with gauged flood data (Stedinger and Baker, 1987). An increase in palaeoflood studies worldwide has caused a significant improvement in the statistical models that can effectively analyze these data (Harden et al., 2011). Various FFA statistical methods are discussed by Frances (2004). In the present study, the palaeoflood data was combined with the limited measured data. In this statistical approach, palaeoflood data is included into the analysis on perception thresholds that efficiently account for censored geologic or historical information. Perception thresholds are stages that reflect the range of flows that would have been recorded for a given year during a specific time period (England et al., 2019). A perception threshold is defined by the elevation of the slackwater deposit site, and the time span that each site is expected to record all floods exceeding the site's elevation. The analysis therefore, relies on the assumption that each flood exceeding the palaeoflood site is recorded in the stratigraphy. The flood frequency analysis was carried out with the PeakFQ 7.2 software (Flynn et al., 2006; Veilleux et al., 2014) where gauged peak flows, historic floods recorded prior to establishment of the gauging station and palaeoflood data are fit to a Log-Pearson Type III distribution. The program applies a generalized method-of-moments estimator denoted the Expected Moments Algorithm (EMA, Cohn et al., 1997), and a generalized version of the Grubbs-Beck test for identifying multiple Potential Influential Low Flows (PILFs; Cohn et al., 2013). These zero or very low values are common in ephemeral streams and they may have excessive influence on the estimated frequency of large floods (Veilleux et al., 2014). Identification of PILFS can greatly improve estimated frequency of large floods.

\section{Results}

The slackwater flood deposits were identified in several sites along the valley margins as overbank deposits and in rock alcoves. Each of these sites preserves evidence of 2-6 palaeoflood units. Our concept was to document as many sites as possible along a defined uniform segment of the channel in order to maximize the palaeohydrological data and to compensate for the small number of palaeoflood data at each site. Although some of the sites are located at channel curvatures where water surfaces are super-elevated, these sites were also analyzed and corrected conservatively. The sedimentary units are usually horizontally bedded, fining upward from coarse sand to silt and occasionally coarsening upward; some sedimentary units are massive. Sedimentary structures such as ripples and cross-bedding were found in sites that are close to the channel and not fully sheltered. Driftwood lines composed of datable organic matter (charcoal and wood), were used as PSIs and for radiocarbon dating. OSL dating was applied for significant sedimentary units, such as the lowest units in each section.

\subsection{Palaeoflood chronology}

The flood timing of the main stratigraphic sites was obtained from a combination of radiocarbon and OSL ages. Regarding the OSL dating, the scatter in the distribution of the equivalent dose (De) values for some samples is very high, with over-dispersion (OD in Table 3) $>80 \%$, much higher than the $20 \%$ over-dispersion observed on well bleached samples (e.g. RAF-1; Table 3). This overdispersion indicates insufficient bleaching of the OSL signal for the quartz grains at the time of deposition. For other samples, the OD values are more acceptable, particularly when considering that 1-mm aliquots were measured. In stratigraphic sets with radiocarbon and OSL dating, the radiocarbon ages (Table 2) were consistently younger than the OSL ages, supporting the interpretation of partial OSL bleaching.

To obtain a better estimate of the time of deposition of the SWD for the highly scattered samples, OSL ages were also calculated from the youngest aliquots, which would represent the best bleached grains ("Youngest age" in Table 3). This provided over-estimated ages, but they are more consistent with the radiocarbon ages.

The dating results indicate relatively young palaeoflood ages. In N. Ze'elim, three out of four radiocarbon ages were modern (Table 2), and the OSL ages, calculated either from the entire data or the youngest aliquots, range between $400-500$ years (before 2018) (Table 3). The ages of the palaeofloods at N. Rahaf appear to be older; their radiocarbon ages range between $2910 \mathrm{BC}$ to 1949 cal. CE (Table 2) and the OSL ages range between $7.3 \pm 1.3$ and 0.7 ky (Table 3).

For example, Unit 1 at site RAF-U in N. Rahaf, was dated by both radiocarbon and OSL to 1448-1630 cal CE (Table 5) and 7.3 \pm 1.3ky BP, respectively, showing a considerable difference between the two dating methods. In contrast, the two methods were used to date the underlying archaeological site at the RAF-G (see Section 4.3.1) and the results provided a radiocarbon age of 30,274 to 29,135 cal BCE (Table 2) and an OSL age of $22 \pm 6 \mathrm{ky}$, which was obtained for the uppermost part of the archaeological unit (Table 3 ). 


\subsection{Palaeoflood hydrology — Nahal Ze'elim}

The study reach is about $900 \mathrm{~m}$ long and located at the lower canyon of N. Ze'elim (Fig. 1) where the drainage area is $246 \mathrm{~km}^{2}$. The width of the channel is $25-80 \mathrm{~m}$ and the average slope is 0.01 . A new gauging station $\left(246 \mathrm{~km}^{2}\right)$, which operates since 2016 , is located at cross-section no. 1 (Figs. 2, 4). Five SWD sites were documented along the reach, all of which are overbank deposits. Each sequence consisted of 2-6 well-bedded, sandy-silty depositional units related to flood events and driftwood lines (Table 4).

These sites were used for further stratigraphic and sedimentological analyses (Fig. 3).

\subsubsection{Palaeoflood stratigraphy}

4.2.1.1. Site ZE-9 (Coordinates: $723626 / 3471269$ ). The site is located on the right bank where the channel width is $\sim 20 \mathrm{~m}$ (Fig. 2 ). It contains six sedimentary units and comprises two adjacent SWD sequences, $3.5 \mathrm{~m}$ and $4.3 \mathrm{~m}$, respectively above the channel bed, 60 $\mathrm{cm}$ and $100 \mathrm{~cm}$ thick, respectively. Units 1 and 6 were dated by OSL to 0.4 and $0.5 \mathrm{ky}$, respectively (Fig. 3).

4.2.1.2. Site ZE-11 (Coordinates: 722980/3471267). The site is located on the left bank behind a large boulder where the channel width is $\sim 17 \mathrm{~m}$ (Fig. 2). The section is $1.6 \mathrm{~m}$ thick and composed of five SWD units (units 2-6; unit 1 is greenish clay which is not a SWD). The elevation of the uppermost unit is $4.2 \mathrm{~m}$ above the channel bed. The uppermost unit (Unit 6) was dated by OSL to $0.4 \pm$ $0.1 \mathrm{ky}$, whereas the lowest unit (Unit 2) yielded a modern radiocarbon age of 1959-1985 cal CE (Fig. 3, Table 4)).

4.2.1.3. Site ZE-12 (Coordinates: $723629 / 3471321$ ). The site is located on a high terrace on the right bank at the internal side of a channel bend (Fig. 2), where water surface elevation, for large floods, is significantly lower. The width of the channel is $\sim 35 \mathrm{~m}$ and the site preserves three depositional units with ripples and cross-bedding. The section is $0.9 \mathrm{~m}$ thick and the elevation of the uppermost unit is $3.4 \mathrm{~m}$ above the channel bed. The lowest unit (Unit 1) yielded a modern radiocarbon age of 2003-2007 cal CE (Fig. 3, Table 4).

4.2.1.4. Site ZE-13 (Coordinates: $723436 / 3471370$ ). The site is located $\sim 200 \mathrm{~m}$ upstream of site ZE-12, on a straight segment of the study reach on the right bank, and is attached to a terrace wall (Fig. 2). The channel width is $\sim 65 \mathrm{~m}$. A well-developed biogenic crust overtops the section indicating a relatively old age for the sediments and long exposure time. The section is $40 \mathrm{~cm}$ thick, and consists of three depositional units. The elevation of the uppermost unit is $3 \mathrm{~m}$ above the channel bed. Unit 3 yielded a radiocarbon age of 1661 - to the present cal CE (Fig. 3).

4.2.1.5. Site ZE-14 (Coordinates:723074/3471265). The site is located the right bank and consists of a high driftwood line of wood and charcoal. It is $5 \mathrm{~m}$ above the channel bed (Fig. 2). The wood yielded a modern radiocarbon age of 1980-1982 cal CE (Fig. 3). This driftwood line documents the highest water level along this stream, with a calculated peak discharge of $900 \mathrm{~m}^{3} \mathrm{~s}^{-1}(\mathrm{Table} 4)$.

Table 5

Palaeoflood data and flood record of Nahal Rahaf.

\begin{tabular}{|c|c|c|c|c|}
\hline Flood no. & Site & Peak Discharge $\left(\mathrm{m}^{3} \mathrm{~s}^{-1}\right)$ & Age & Source/type of data \\
\hline 1 & $\mathrm{HS}^{\mathrm{a}}$ & $525 / 775$ & *Oct 1987 & Polak, 1988 / historical \\
\hline 2 & $\mathrm{HS}^{\mathrm{a}}$ & 210 & *May 2014 & $*$ IHS \\
\hline 3 & $\mathrm{HS}^{\mathrm{a}}$ & 200 & *Oct 1997 & *IHS \\
\hline 4 & $\mathrm{HS}^{\mathrm{a}}$ & 180 & *April 2018 & *IHS \\
\hline 5 & $\mathrm{HS}^{\mathrm{a}}$ & 153 & *May 1997 & *IHS \\
\hline 6 & $\mathrm{HS}^{\mathrm{a}}$ & 118 & *March 1991 & *IHS \\
\hline 7 & RAF-G-3 & 1250 & & ${ }^{\mathrm{P}} \mathrm{DWL}$ \\
\hline 8 & RAF-G-2 & 1170 & **1667-1941 cal CE (1725-1783 CE 39.5\%) & ${ }^{\mathrm{P}} \mathrm{SWD}$; DWL \\
\hline 9 & RAF-G-1 & 1130 & $\left({ }^{\wedge} 22 \pm 6 \mathrm{ky}\right)$ & ${ }^{\mathrm{p}} \mathrm{SWD}$ \\
\hline 10 & RAF-D & 500 & & ${ }^{\mathrm{P}} \mathrm{SWD}$ \\
\hline 11 & RAF-B1-2 & 400 & & ${ }^{\mathrm{P}}$ SWD \\
\hline 12 & RAF-B1-1 & 370 & ${ }^{\#} 0.7 \mathrm{ky}$ & ${ }^{\mathrm{P}} \mathrm{SWD}$ \\
\hline 13 & RAF-B1-DWL & 350 & & ${ }^{\mathrm{P}} \mathrm{SWD}$ \\
\hline 14 & RAF-G-BOR-5 & 320 & & ${ }^{\mathrm{P}}$ Coarse SWD;DWL \\
\hline 15 & RAF-G-BOR-4 & 300 & & ${ }^{\mathrm{p}} \mathrm{SWD}$; DWL \\
\hline 16 & RAF-G-BOR-3 & 240 & **360-192 cal BCE (354-201 cal BCE 68\%) & ${ }^{\mathrm{P}} \mathrm{SWD}$; DWL \\
\hline 17 & RAF-U-2 & 200 & & ${ }^{\mathrm{P}} \mathrm{SWD}$ \\
\hline 18 & RAF-G-BOR-1 & 200 & $* * 2911-2879$ cal BCE $(2903-2887$ cal BCE $68 \%)$ & ${ }^{\mathrm{p}} \mathrm{SWD}$; DWL \\
\hline 19 & RAF-U-1 & 170 & $\begin{array}{l}* * 1448-1630 \mathrm{cal} \mathrm{CE}(1448-1523 \mathrm{CE} 64.4 \%) \\
{ }^{*} 7.3 \pm 1.3 \mathrm{ky}\end{array}$ & ${ }^{\mathrm{P}} \mathrm{SWD}$; DWL \\
\hline
\end{tabular}

${ }^{\text {a }}$ Hydrometric station of the Israel Hydrological Service (IHS) located at the outlet of the stream $\left(77 \mathrm{~km}^{2}\right)$, active since 1991 .

* Measured flood.

p Paleoflood; SWD - slackwater deposit; DWL - driftwood line.

${ }^{* *} \mathrm{C}$ age.

\# OSL age (ky before 2018). 'OSL age does not fit the stratigraphy at the site (see Section 4.3.1). 


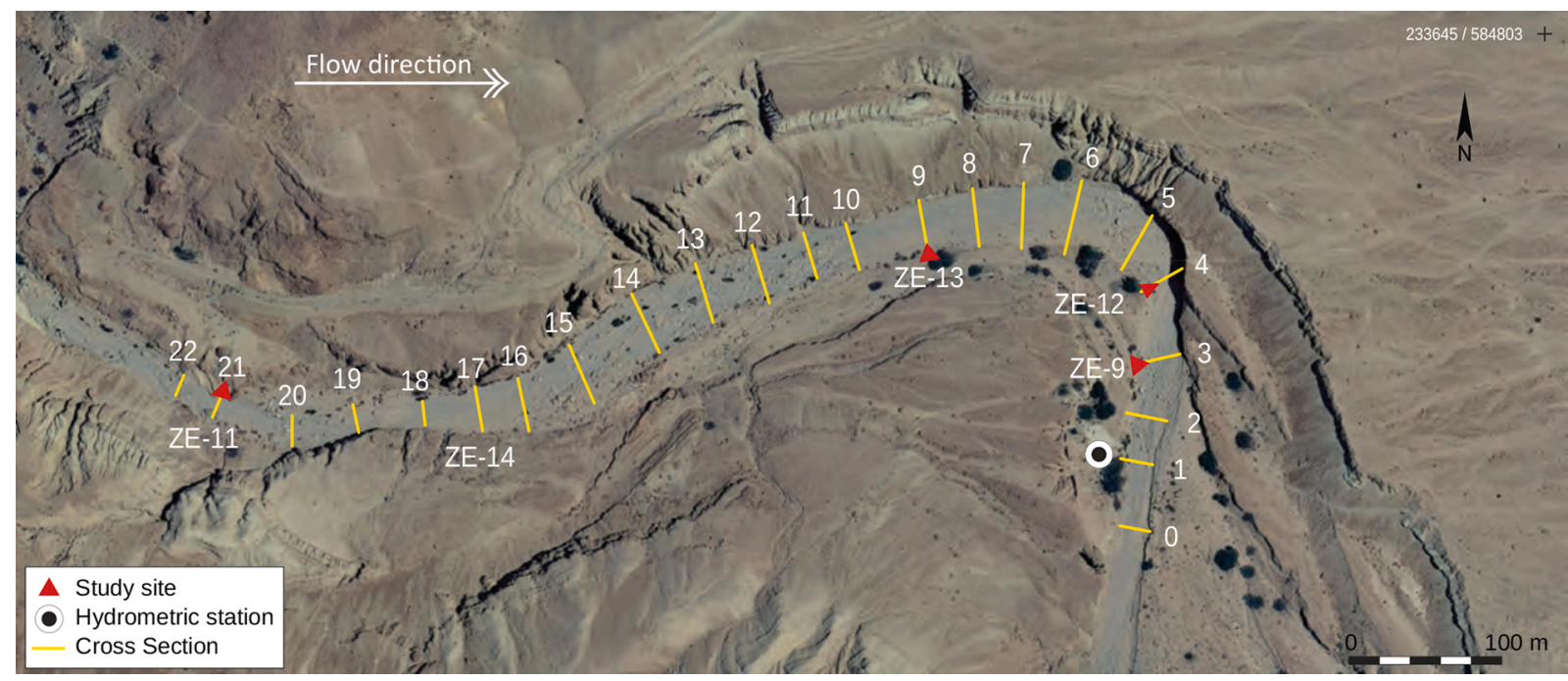

Fig. 2. The Nahal Ze'elim study reach and sites. The hydrometric station is located at cross section (XS) no. 1 . The 23 cross sections are between 25-80 m wide and are spaced between $24-74 \mathrm{~m}$ of each other (about $40 \mathrm{~m}$ in average). Note that site ZE- 12 located on the internal side of a bend, therefore, HECRAS water surface profiles underestimate the peak discharges of floods. Source of airphoto: Survey of Israel - govmap.gov.il.

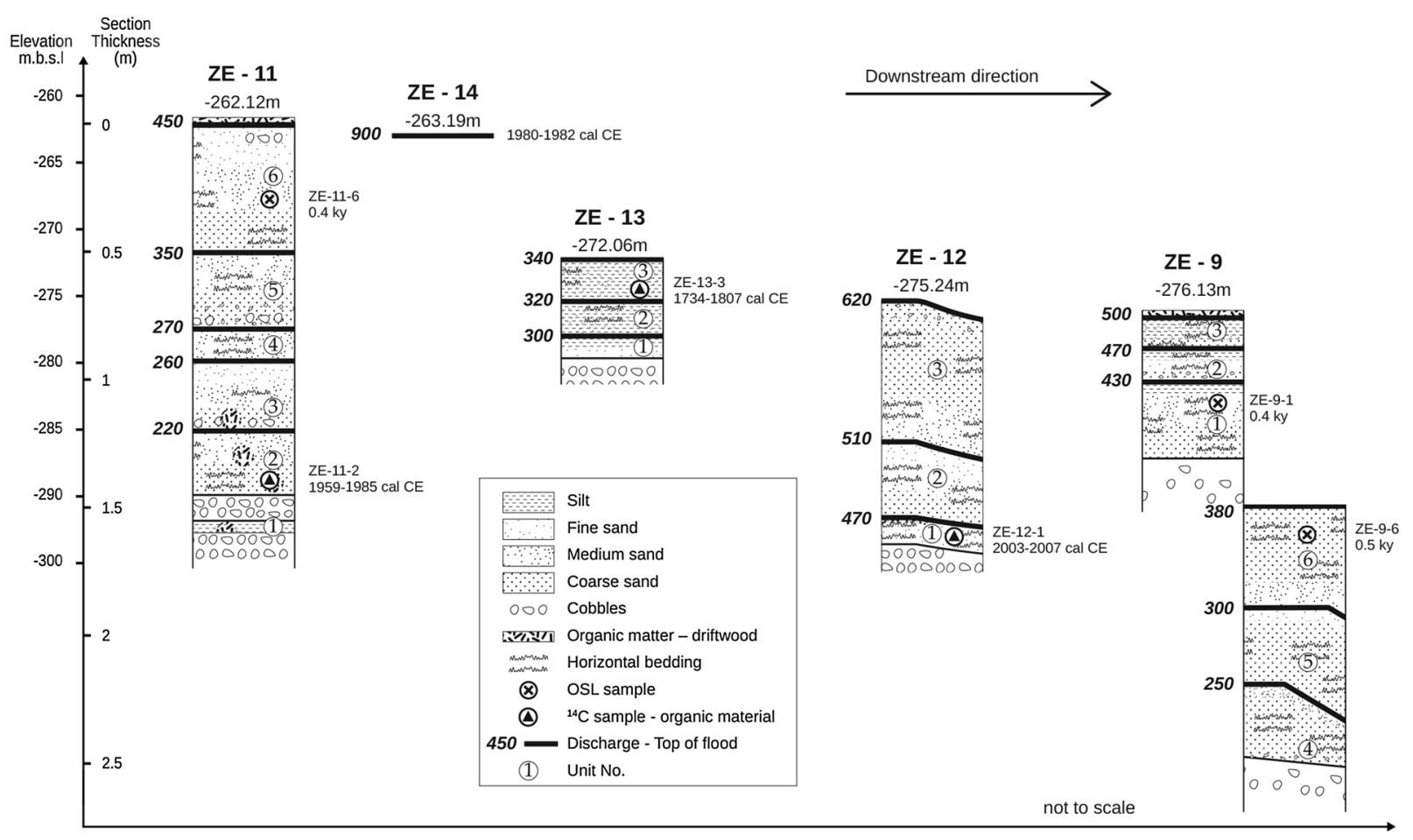

Fig. 3. Stratigraphic sections along N. Ze'elim including ages, sediment properties, elevation (in meters b.s.l) and the section thickness. Peak discharges are presented on the left side of the top of each sedimentary unit. Location and elevation of the sedimentary sections along the channel are presented in Fig. 4.

\subsubsection{Peak discharge determinations}

The HEC-RAS procedure generated water surface profiles in a subcritical flow regime for the entire reach that are typical for large floods in bedrock canyons (Ely and Baker, 1985; O'Connor and Webb, 1988; Greenbaum et al., 2001). Manning $\boldsymbol{n}$ values range from 0.035-0.045 and the downstream boundary condition was normal depth (Fig. 4). The high water marks of the April 2018 flood - 380 $\mathrm{m}^{3} \mathrm{~s}^{-1}$ (Israel Hydrological Service, 2018) helped to calibrate the HEC-RAS water surface profiles along the study reach. Water surface profiles were iterated for discharges of 300-900 $\mathrm{m}^{3} \mathrm{~s}^{-1}$ (Fig. 4). The largest reconstructed peak discharge was $900 \mathrm{~m}^{3} \mathrm{~s}^{-1}$ in comparison 


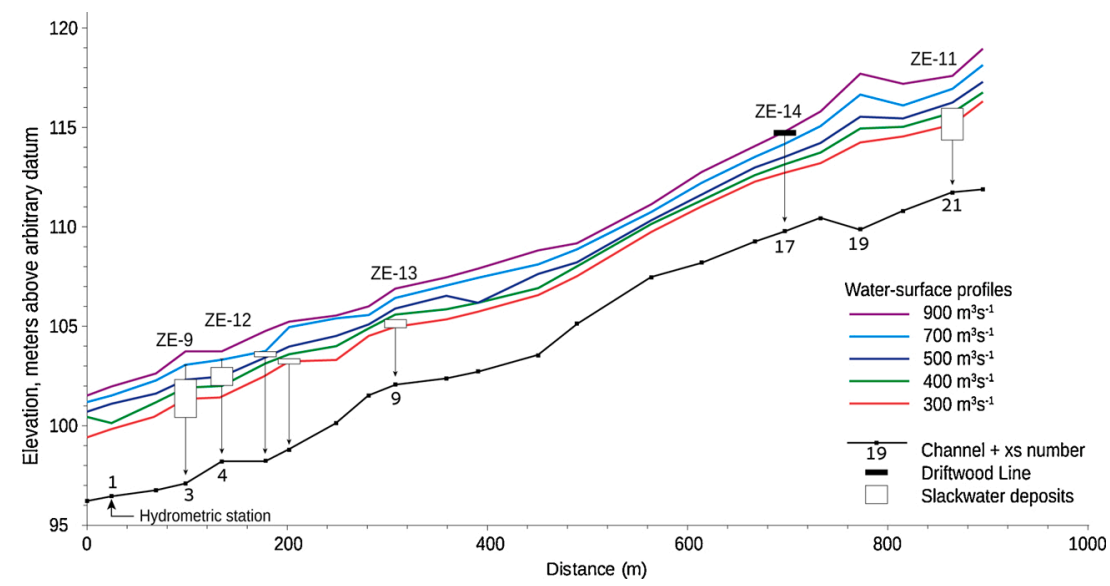

Fig. 4. N. Ze'elim, HECRAS - 1D water surface profiles for discharges of $300-900 \mathrm{~m}^{3} \mathrm{~s}^{-1}$. Note the backwater in XSs-18-20 which is caused by the channel constriction.

to the maximum observed 1997-flood of $680 \mathrm{~m}^{3} \mathrm{~s}^{-1}$ (1.3 times larger). The peak discharges for site ZE-12, were corrected due to its location. This correction increased the water surface elevations by $25-50 \mathrm{~cm}$ and the peak discharges by $8-10 \%$.

\subsection{Palaeoflood hydrology - Nahal Rahaf}

The study reach is $520 \mathrm{~m}$ long and located in the upper N. Rahaf canyon. The drainage area for this reach is $55 \mathrm{~km}^{2}$ (Fig. 1). The bedrock channel at the site consists of a relatively straight segment with one major curvature. The channel is between 15 and $40 \mathrm{~m}$ wide with an average slope of 0.02 (Fig. 5). The gauging station, which has been active since 1991, is located close to the stream outlet (drainage area of $75 \mathrm{~km}^{2}$ ).

Four SWD sites along the reach were documented, sampled and analyzed. Each sequence preserved 2-3 flood events, including driftwood lines (Table 5).

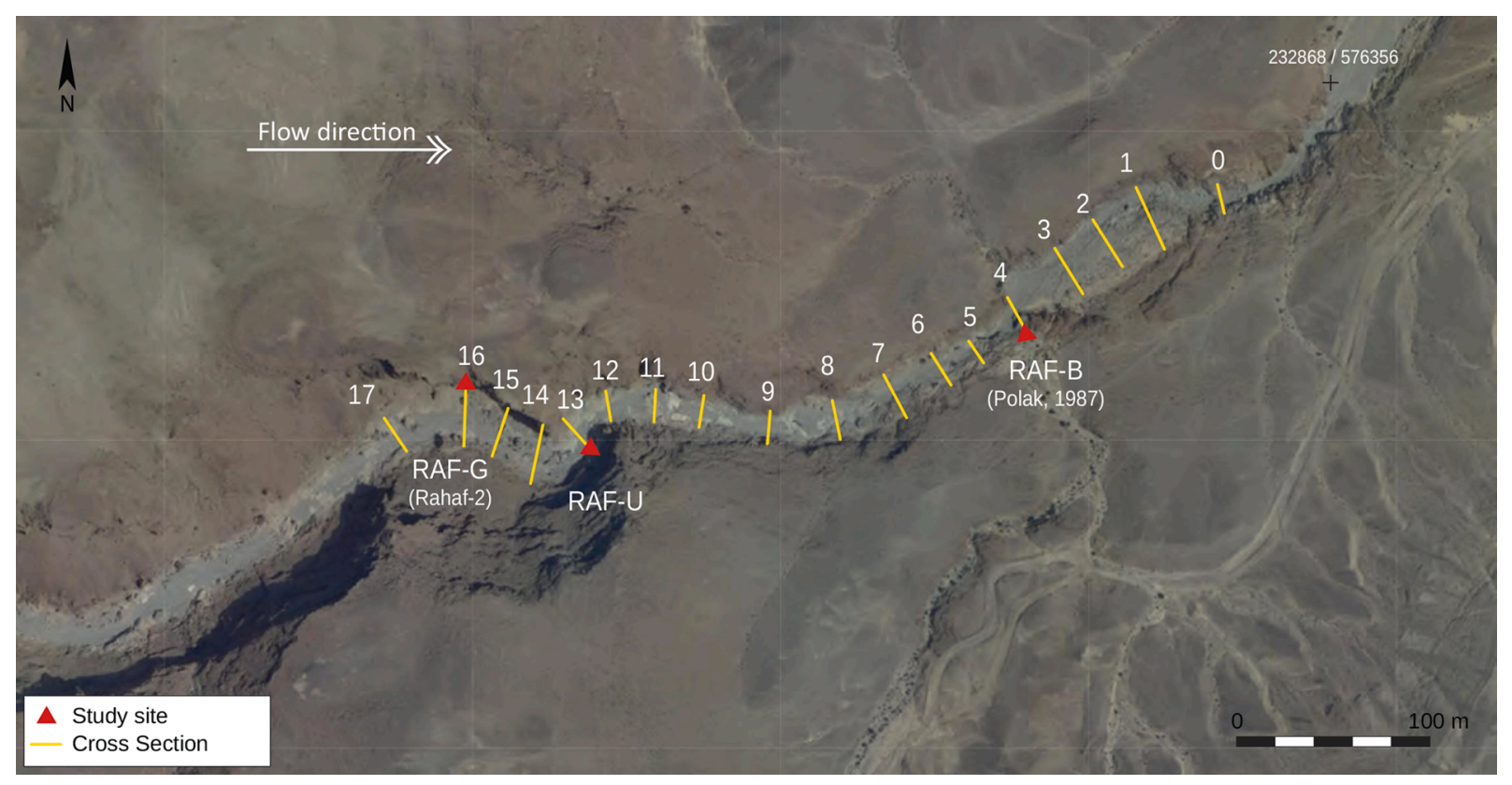

Fig. 5. Nahal Rahaf study reach and sites.. The 18 cross sections range in width from 12 to $42 \mathrm{~m}$ and are spaced between $13-50 \mathrm{~m}$ apart. Crosssections 13-14 indicate super-elevated water surface at the right bank, whereas cross-sections 15-16 at the left bank. Note that sites RAF-U and RAF$\mathrm{G}$ are located at the external side of the bend, providing over-estimated peak discharges and therefore were corrected and reduced. Source of airphoto: Survey of Israel - govmap.gov.il. 


\subsubsection{Palaeoflood stratigraphy}

4.3.1.1. Site RAF-B (Coordinates: $723125 / 3462942)$. The site is located on a rock strath covered by boulders. It is situated on the right bank, which is the canyon wall, $5.3 \mathrm{~m}$ above the channel bed (Fig. 5). The SWD sequence is $15-25 \mathrm{~cm}$ thick and consists of two sedimentary units; the lower unit (unit 1) was deposited directly over the bedrock bank and dated by OSL to 0.7 ky (Fig. 8). A clear, somewhat lower driftwood line is located at the site and along this segment.

4.3.1.2. Site RAF-U (Coordinates: $722909 / 3462888$ ). The site is located within an alcove/rock shelter $3.9 \mathrm{~m}$ above the channel bed on the right bank (Fig. 5). The sequence is $75 \mathrm{~cm}$ thick and has two sedimentary units (Fig. 8). The lower unit (unit 1) was deposited directly over the bedrock bottom of the alcove and is overtopped by a layer of organic debris radiocarbon dated to $1448-1630$ cal CE (Table 5). This unit was also dated by OSL to $7.3 \pm 1.3 \mathrm{ky}$. The site is located at a super-elevated floodwater surface and therefore the height and peak discharges were corrected and reduced by $20-30 \mathrm{~cm}$. Peak discharges for this site range between $170-200 \mathrm{~m}^{3} \mathrm{~s}^{-1}$.

4.3.1.3. Site RAF-G (Coordinates: 722803/3462894). The site is located on the left bank, upstream of a channel curvature within a rock shelter $\sim 8 \mathrm{~m}$ above the channel bed, where the channel width is $\sim 50 \mathrm{~m}$ (Figs. 5,8 ). High driftwood and two sedimentary units were documented within the rock shelter (Fig. 6). The sedimentary units were found to overlie a newly exposed Upper Paleolithic archaeological site, which includes flint artifacts, ash, bones, and charcoal dated by radiocarbon to 30,275-29,135 cal yr BCE (Table 2;

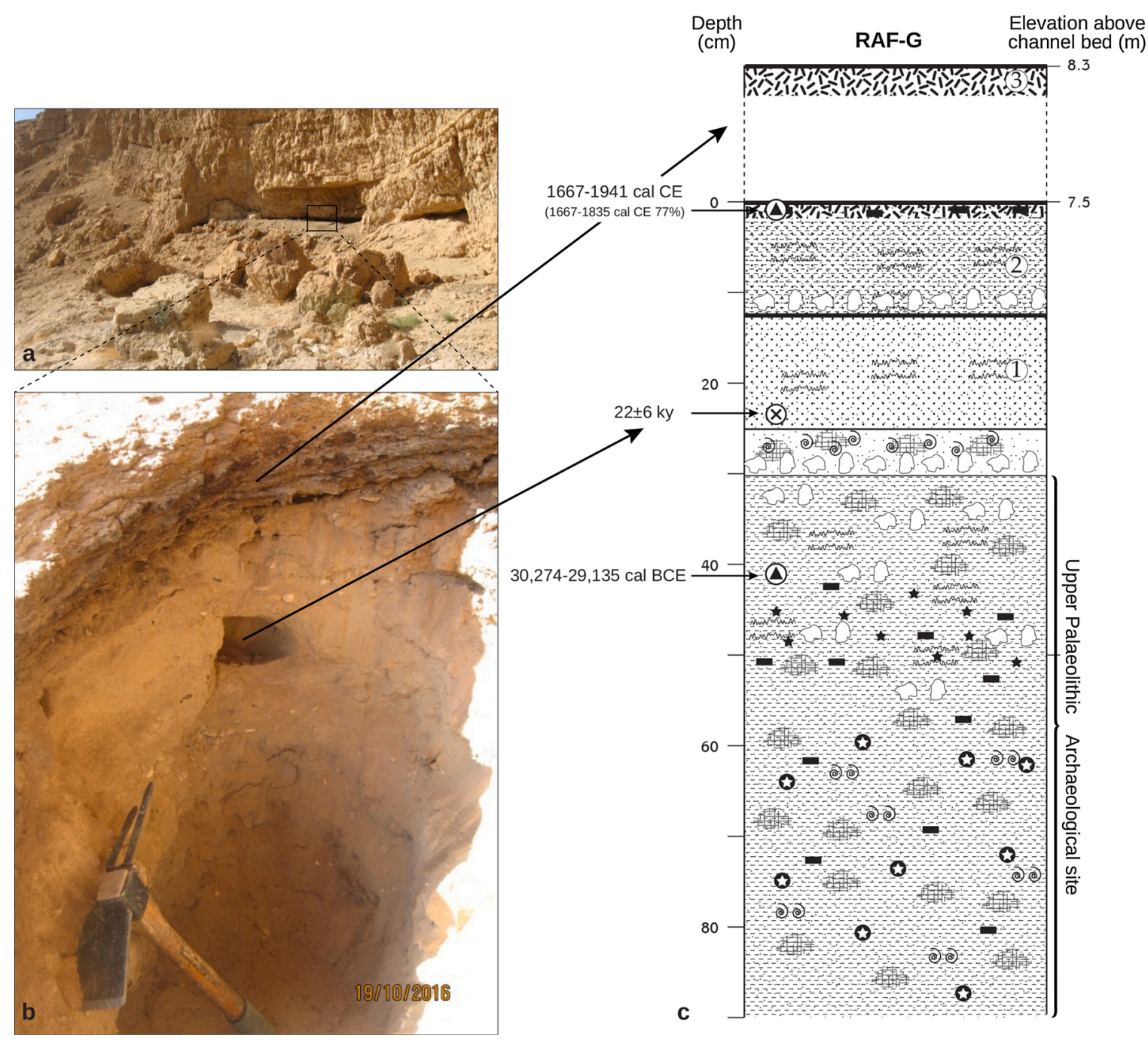

Fig. 6. RAF-G site. (a) The rock-shelter in which the site is located (b) A pit showing the palaeoflood sedimentary units and the underlying UP archaeological site. The uppermost $15 \mathrm{~cm}$ are composed of goat feces indicating present occupation. (c) The old OSL age of unit $1-22 \pm 6 \mathrm{ky}$, is related to the sampling which mixed sediments from both unit 1 and the underlying archaeological unit. (For sediment properties see legend in Fig. 8). Units 1-3 are super-elevated, were corrected and provide reconstructed peak discharges of 1130-1250 $\mathrm{m}^{3} \mathrm{~s}^{-1}$, respectively (see Fig. 9). 
Fig. 6). The site was excavated by the Israel Antiquity Authority and by the University of Haifa in March 2019 (Barzilai et al., 2020). Few angular clasts from the roof of the shelter with overlying land-snail shells cover the top of the archaeological unit. The overlying units are clearly, well-bedded SWDs, containing a. The lower unit (Unit 1) was dated by OSL to $22 \pm 6 \mathrm{ky}$, which is clearly too old for the SWD. Most likely part of the sample came from the underlying UP archaeological site, though this was unknown at the time of sampling (Figs. 6, 8). The upper unit (Unit 2), is overtopped by a layer of woody debris and charcoal, dated by radiocarbon to 1667-1941 cal CE (Table 5). The entire section and most of the rock-shelter floor, are covered by a massive $15 \mathrm{~cm}$ layer of goat dung, indicating modern human activity. The site is located at the external bank of channel curvature and therefore is significantly super-elevated for large floods (Fig. 5). The peak discharges were corrected and reduced, accordingly, by up to $12 \%$. The driftwood at the site marks the highest water level for this reach - reconstructed peak discharge of about $1250 \mathrm{~m}^{3} \mathrm{~s}^{-1}$.

4.3.1.4. Site RAF-G-bor (Coordinates: 722803/3462894). The site is located adjacent to RAF-G, some $3.2 \mathrm{~m}$ above the channel bed (Fig. 8). Units 1, 3 and 4 are well-bedded SWDs, whereas Unit 2 is massive, fine-grained, composed mainly of ash, organic matter and charcoal, and is probably an archaeological unit (Fig. 7). Unit 1 is relatively coarse, and was deposited directly over a bedrock shelf. It contains organic matter and burned wood, dated by radiocarbon to 2910-2880 cal BCE (Table 5). Unit 3 is capped by two layers of organic matter, the lower of which was dated by radiocarbon to 360-190 cal BCE (Table 5). The maximum reconstructed peak discharge for this section was $300 \mathrm{~m}^{3} \mathrm{~s}^{-1}$. A mound of relatively fresh and coarse SWDs with overtopping driftwood deposited nearby, attributed a peak discharge of $320 \mathrm{~m}^{3} \mathrm{~s}^{-1}$ (Fig. 8).

\subsubsection{Peak discharge determinations}

HEC-RAS water surface profiles were iterated in subcritical flow regime along the $520 \mathrm{~m}$ long reach. Manning $\boldsymbol{n}$ values range between $0.035-0.045$ and the downstream boundary condition was normal depth (Fig. 9).

According to the gauging station $\left(77 \mathrm{~km}^{2}\right.$ ), the April 2018 flood generated a discharge of $180 \mathrm{~m}^{3} \mathrm{~s}^{-1}$ (Israel Hydrological Service, 2018), which calibrates the HEC-RAS water surface profiles. Water surface profiles were iterated for discharges of $200-1400 \mathrm{~m}^{3} \mathrm{~s}^{-1}$. The elevations and peak discharges for sites RAF-G and RAF-U were corrected due to their super-elevated location. The range of corrections is $62-75 \mathrm{~cm}$ for site RAF-G and $20-35 \mathrm{~cm}$ for site RAF-U. These differences cause a change of about $12 \%$ in peak discharges. The maximum peak discharge of about $1250 \mathrm{~m}^{3} \mathrm{~s}^{-1}$ reconstructed for the $R A F-G$ rock shelter site, is $>2$ times larger than the maximum historical flood of October $1987-525 \mathrm{~m}^{3} \mathrm{~s}^{-1}$ (Polak, 1988).

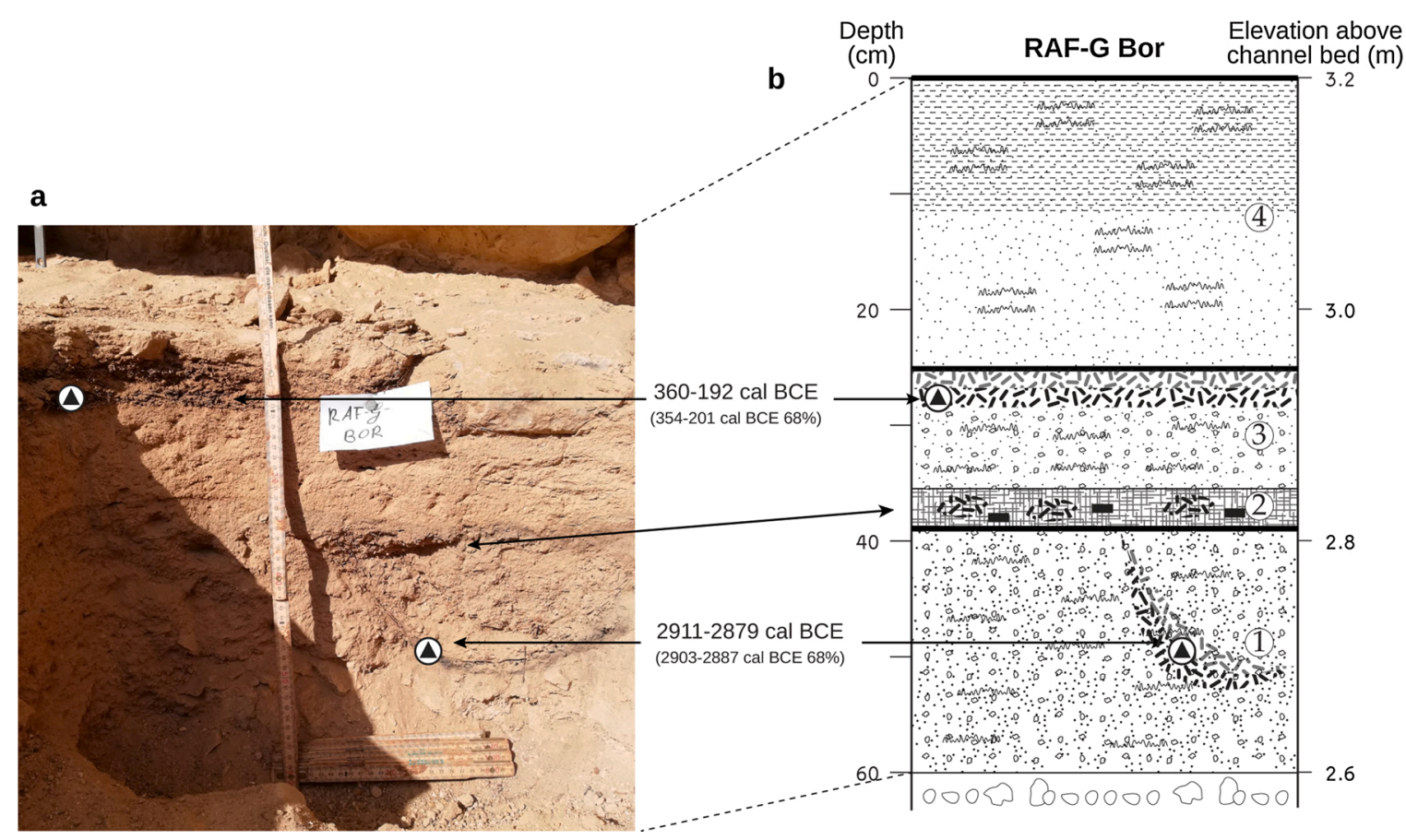

Fig. 7. RAF-G-bor site: Picture (a) and stratigraphic section (b) showing three well-bedded SWD units - units 1,3,4. Unit 2 is massive, fine-grained and is probably an archaeological unit. Unit 1, radiocarbon dated to about 5000 years BP is the oldest sedimentary unit for the study reach. For legend of sedimentary units see Fig. 8. Reconstructed peak discharges range between $200-300 \mathrm{~m}^{3} \mathrm{~s}^{-1}$ (see Figs. 8 and 9). 


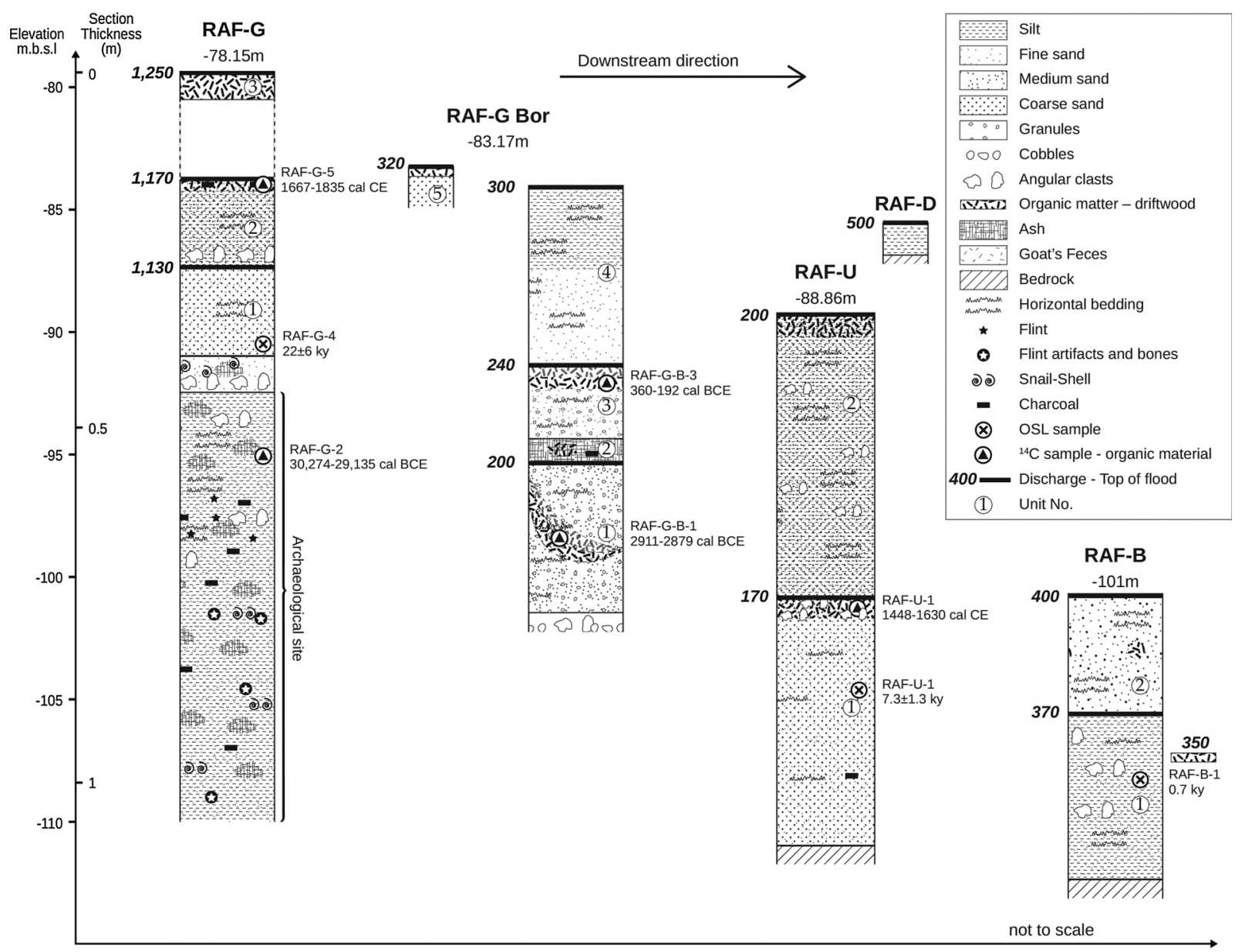

Fig. 8. N. Rahaf stratigraphic sections including ages, sediment properties, elevation (in meters b.s.l), and section thickness. The actual elevation of the section is indicated above. Peak discharges are presented on the left side of each section, at the top of each flood sedimentary unit. Location and elevation of the sedimentary sections along the channel are presented in Fig. 9. Note that the peak discharge for the SWDs at sites RAF-G and RAF-U located at the left bank and the right bank, respectively (Fig. 5), are super-elevated and were corrected. The highest driftwood line in site RAF-G is associated with peak discharge of $1250 \mathrm{~m}^{3} \mathrm{~s}^{-1}$.

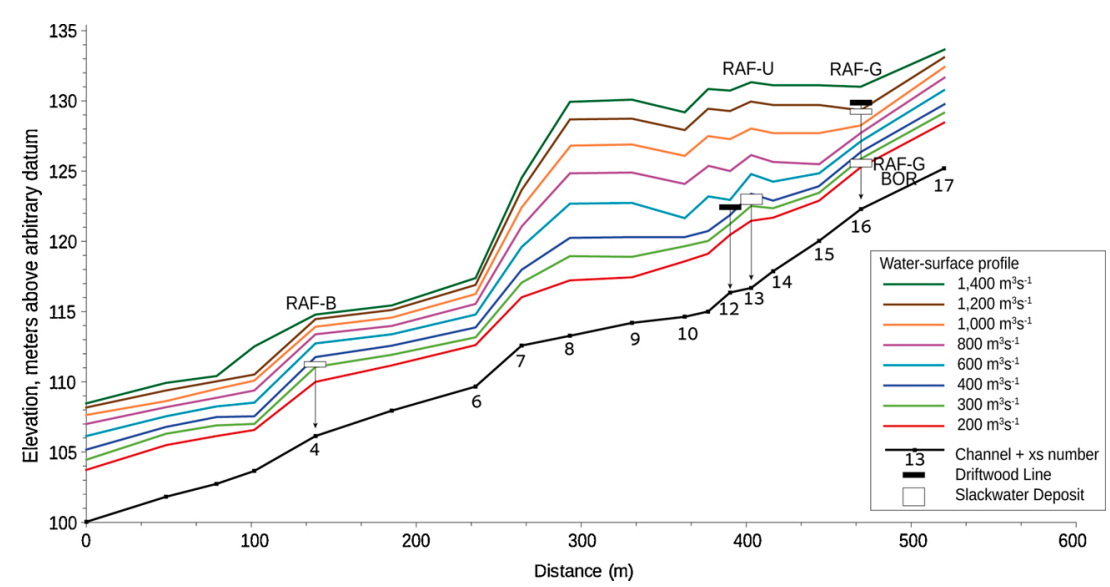

Fig. 9. Water surface profiles for discharges of $200-1400 \mathrm{~m}^{3} \mathrm{~s}^{-1}$ along N. Rahaf including location and elevation of palaeoflood study sites. XSs 7 and 8 are narrower causing a major backwater in cross sections $8-11$. 


\section{Discussion}

\subsection{Palaeoflood records and magnitudes}

The steep mountainous Judean Desert streams preserve evidence of large palaeofloods. Our study sites were selected according to the preservation of SWD sequences with respect to the geometry of the channel reaches (Figs. 2, 5) trying to avoid irregularities such as waterfalls and abrupt changes in channel width - expansions and constrictions, in order to enable best hydraulic modelling.

\subsubsection{Nahal Ze'elim}

Eighteen flood depositional units were documented along the entire study reach and additional four large observed floods since 1997, with peak discharges ranging between 100 and $680 \mathrm{~m}^{3} \mathrm{~s}^{-1}$ (Table 4). Four floods were found to overlap based on age and peak discharge, leaving eighteen distinct flood events with discharges ranging between 100 and $900 \mathrm{~m}^{3} \mathrm{~s}^{-1}$. Six of them range in discharge between 400 and $500 \mathrm{~m}^{3} \mathrm{~s}^{-1}$, four exceeded $500 \mathrm{~m}^{3} \mathrm{~s}^{-1}$, and one palaeoflood surpassed the 1997 -flood $\left(680 \mathrm{~m}^{3} \mathrm{~s}^{-1}\right)$. Seven palaeofloods were dated either by radiocarbon or OSL, all of which were younger than 500 years (Tables 2,3 ). The maximum palaeo- peak discharge of $900 \mathrm{~m}^{3} \mathrm{~s}^{-1}$ was radiocarbon dated to $1980-1982 \mathrm{CE}$. The palaeoflood record is about $82 \%$ of the total hydrological record.

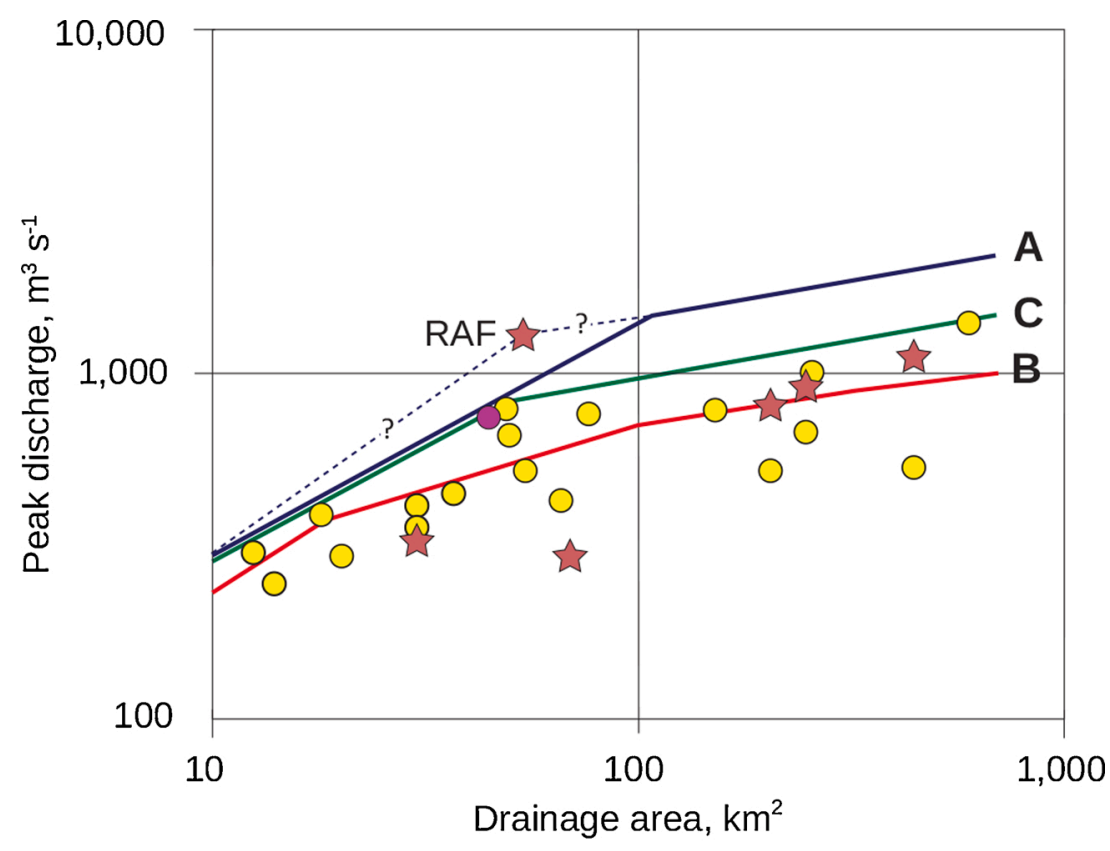

Floods in the Dead Sea Region
O Measured/observed floods
Paleofloods - Hatzera Basin (Greenbaum et al., 2020)
Envelope curves
A P Paleofloods of the NE Negev and Dead Sea Region
(Greenbaum et al. 2001)
C Measured floods of the Negev
(Meirovich et al. 1998)
Measured floods of the Dead Sea region after 2004
(Greenbaum et al. 2010)

Fig. 10. Maximum palaeo-peak discharges in Nahal Ze'elim and Nahal Rahaf in relation to various envelope curves: (A) the largest palaeoflood peak discharges in the Negev and southern Judea deserts (Greenbaum et al., 2001); (B) Measured floods of the Negev desert region (Meirovich et al., 1998) and (C) Measured floods of the Dead Sea region (Greenbaum et al., 2010). Note that the maximum palaeo-peak discharge at the Nahal Rahaf significantly exceeds the palaeo-envelope curve (A), whereas at the much larger Nahal Ze'elim it is only slightly larger than the measured envelope curve (B). 


\subsubsection{Nahal Rahaf}

Thirteen flood depositional units were documented along the entire reach. The gauged record since 1991 includes five large floods with peak discharges between 118 and $210 \mathrm{~m}^{3} \mathrm{~s}^{-1}$ and one historical flood with discharges of $525 \mathrm{~m}^{3} \mathrm{~s}^{-1}\left(775 \mathrm{~m}^{3} \mathrm{~s}^{-1}\right.$ at the outlet). Seven floods were found to overlap based on age and peak discharge. This leaves twelve distinct floods with peak discharges between 118 and $1250 \mathrm{~m}^{3} \mathrm{~s}^{-1}$ (Table 5). The radiocarbon ages range between $2910 \mathrm{BCE}$ to $1940 \mathrm{CE}$ (about 5000 years) and the OSL ages go back to $7.3 \pm 1.3 \mathrm{ky}$ (Tables 2,3 ). The second largest palaeoflood with a peak discharge of $1170 \mathrm{~m}^{3} \mathrm{~s}^{-1}$ was radiocarbon dated to $<1667-1941$ CE. The palaeoflood record therefore comprises about $68 \%$ of the large floods $\left(>100 \mathrm{~m}^{3} \mathrm{~s}^{-1}\right)$ in the combined records. The systematic record includes another twenty-three floods with peak discharge $<100 \mathrm{~m}^{3} \mathrm{~s}^{-1}$.

In the large ephemeral streams of the Negev the preservation of palaeoflood deposits, usually in tributary mouths, was relatively good with an average of 10-15 flood deposits at each site (Greenbaum et al., 2006; Table 1). In contrast, at the smaller and steeper, southern Judean Desert streams, such as in the present study, flood deposition usually occurs on discontinuous overbank pockets and in small rock shelters, preserving a limited flood sedimentary record with only 2-6 floods in each site. This makes it more complicated to construct a long-term and significant palaeoflood record, in comparison to the palaeoflood sites in the Negev. Therefore, the data were collected from maximum potential sites along the study reach. Previous studies in two other streams in the southern Judean
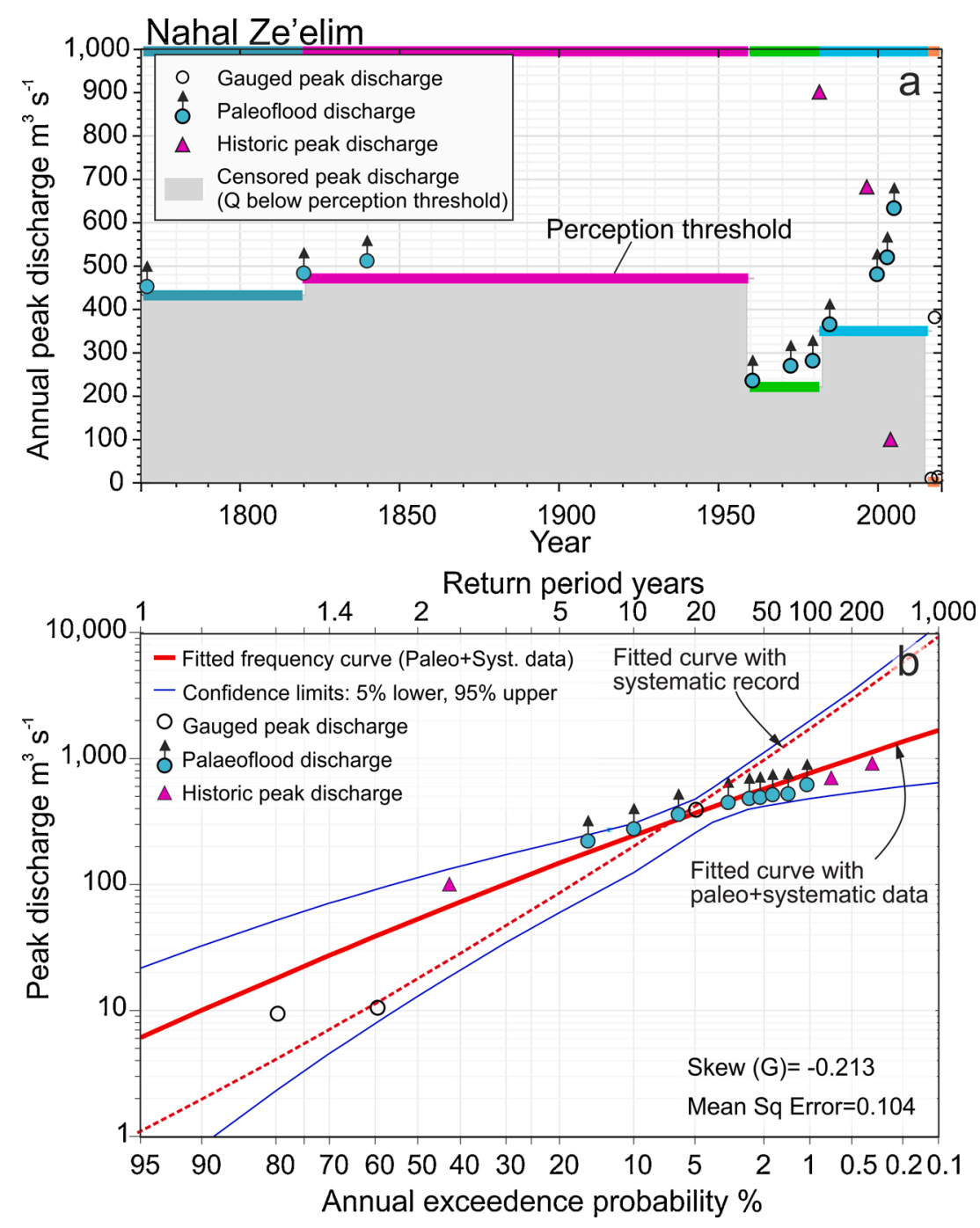

Fig. 11. Nahal Ze'elim flood frequency analysis for. (a) Palaeoflood, historic and systematic discharges. Perception thresholds of $430,480,220$ and $350, \mathrm{~m}^{3} \mathrm{~s}^{-1}$ (from oldest to recent) represent the minimum discharge associated with the palaeoflood sites used in the FFA. The palaeoflood and historical information is described as binomial-censored observations corresponding to exceedances of a perception threshold (data bullets) or being below (non-exceedances, grey area) the threshold for any given year. (b) Annual exceedance probability plot with the fitted Log-Pearson Type III (LP3) frequency curve (solid red line) using palaeoflood (green dots), historic (pink triangles) and systematic (empty dots) data. The blue lines are the upper and lower confidence limits of the fitted curve. The dashed line corresponds to the fitted LP3 distribution using the systematic and historic data only. Note the difference between the two fitted frequency curves with the systematic distribution overestimating the discharge values of the high flood quantiles $(<1 \%$ annual exceedance probabilities). 
Desert, Nahal Heimar $\left(450 \mathrm{~km}^{2}\right.$ ) and Nahal Ashalim $\left(75 \mathrm{~km}^{2}\right.$ ) (Fig. 1), reconstructed maximum palaeo-peak discharges were 1100 and $760 \mathrm{~m}^{3} \mathrm{~s}^{-1}$, respectively (Greenbaum et al., 2006; Table 1). The extremely long palaeoflood record of Nahal Ashalim (7600 years) was preserved in a cave. A comparison of the magnitudes of the largest palaeofloods and measured floods in the Negev and southern Judean deserts and the fitted envelope curves is presented in Fig. 10. The paleohydrological data from these streams shows that our results maximum peak discharges of 900 and $1250 \mathrm{~m}^{3} \mathrm{~s}^{-.1}$ are within the same range. Nevertheless, the maximum peak discharge in $\mathrm{N}$. Rahaf $1250 \mathrm{~m}^{3} \mathrm{~s}^{-1}$ is outstanding for its relatively small basin size, which exceeds the regional envelope curve.

\subsection{Flood frequency analysis (FFA)}

Palaeoflood information relevant for flood frequency analysis comprises peak discharges their ages - absolute or relative, and perception thresholds for individual palaeoflood magnitudes (England et al., 2019). Regarding flood timing, the dated palaeoflood units provide the temporal framework of the palaeoflood record, whereas for the undated units, a relative flood age was assigned based on their stratigraphic position.

The basic assumption in the statistical models using palaeohydrological information is that all floods above a certain perception threshold are documented in the stratigraphic record over a period of known duration. The perception thresholds are stages related to the palaeoflood sites, assuming that each flood with magnitude exceeding the base of the site (alcove or overbank surface), results in an individual flood bed. The flood age of the lowest flood bed within the palaeoflood stratigraphy of the site marks the temporal onset of the perception threshold. As a result, every year there is information about a flood discharge, exceeding or not exceeding, that perception threshold (Benito et al., 2020). In this way, palaeoflood data can be processed as censored data that can be efficiently analyzed by statistical methods (Stedinger and Cohn, 1986; Cloete et al., 2018).

\subsubsection{Nahal Ze'elim}

Fig. 11a shows the flood data organization used in the flood frequency analysis, comprising thirteen floods over the period 1770-2015, and four gauged floods (2016-2019). The palaeoflood data were arranged according to four perception thresholds (PTs): two gradually increased from 430 to $480 \mathrm{~m}^{3} \mathrm{~s}^{-1}$ over the time interval of $1770-1959$ cal. years CE, and two from 220 to $350 \mathrm{~m}^{3} \mathrm{~s}^{-1}$ over the period 1960-2015 cal. years CE. It was assumed that Unit 1 at ZE-9 (OSL age $\sim 0.4$ ky, Fig. 3 ) is equivalent to the Unit 3 at ZE-13 (1734-1807 cal. CE), which is reasonable based on the similarity in discharge between both palaeoflood sites and on the wide range of over-dispersion of the OSL age of Unit 1. Palaeoflood data from sites ZE-9, ZE-11 and ZE-12 (Fig. 3) constrained the lower bound discharge value assigned to the perception thresholds and the individual floods (discharge and age) used for FFA. The non-systematic flood record was completed with the historic floods recorded in $1981\left(900 \mathrm{~m}^{3} \mathrm{~s}^{-1}\right), 1997\left(680 \mathrm{~m}^{3} \mathrm{~s}^{-1}\right)$, and $2004\left(100 \mathrm{~m}^{3} \mathrm{~s}^{-1}\right)$.

The Log Pearson-3 distribution provided a good fit of the systematic + palaeoflood record analysis (Fig. 11b) with the palaeoflood and historical discharges plotted near the fitted distribution, where all data located within the confidence limits indicating a good fit. The upper tail includes the historic floods with discharges of 900 and $680 \mathrm{~m}^{3} \mathrm{~s}^{-1}$, followed by the largest palaeofloods of $620 \mathrm{~m}^{3} \mathrm{~s}^{-1}$. An additional frequency analysis was completed using the gauged (four years) and historical floods (three floods) showing a lack of definition of the distribution upper tail that result in very high discharges for the higher quantiles. For instance, the calculated $1 \%$ annual exceedance probability flood for the palaeoflood + gauged dataset is $760 \mathrm{~m}^{3} \mathrm{~s}^{-1}$, whereas using the gauged + historic record it is $1750 \mathrm{~m}^{3} \mathrm{~s}^{-1}$ (Table 6).

The largest peak discharge of $900 \mathrm{~m}^{3} \mathrm{~s}^{-1}$ in $\mathrm{N}$. Ze'elim attributed a recurrence interval of $<50$ years based on the limited gauge record (including historic floods), and 150-200 years based on the combined gauge, historic and palaeoflood records (Fig. 11b, Table 6). The largest measured discharge $-680 \mathrm{~m}^{3} \mathrm{~s}^{-1}$ assigned annual exceedance probabilities of $3-4 \%$ and $1-2 \%$, respectively.

Table 6

Peak discharge estimates for different annual exceedance probabilities in the Nahal Ze'elim and Nahal Rahaf streams using Log Pearson 3 distribution, fitted to the annual maximum systematic records and to the combined systematic and palaeoflood data. The percentage of change illustrates the variability that results from the use of systematic + palaeoflood compared to the application of conventional methods (i.e. systematic records).

\begin{tabular}{|c|c|c|c|c|c|c|c|}
\hline \multirow{2}{*}{$\begin{array}{l}\text { Annual Exceedance } \\
\text { Probability } \\
(\%)\end{array}$} & \multicolumn{3}{|c|}{ Nahal Ze'elim } & \multicolumn{4}{|c|}{ Nahal Rahaf } \\
\hline & \multirow{2}{*}{$\begin{array}{l}\text { Discharge } \\
\text { Systematic } \\
\text { record } \\
\left(\mathrm{m}^{3} \mathrm{~s}^{-1}\right)\end{array}$} & \multirow{2}{*}{$\begin{array}{l}\text { Discharge } \\
\text { Syst. + palaeo } \\
\text { record } \\
\left(\mathrm{m}^{3} \mathrm{~s}^{-1}\right)\end{array}$} & \multirow{2}{*}{$\begin{array}{l}\text { Change } \\
* \\
\text { (\%) }\end{array}$} & \multirow{2}{*}{$\begin{array}{l}\text { Discharge } \\
\text { Systematic } \\
\text { record } \\
\left(\mathrm{m}^{3} \mathrm{~s}^{-1}\right)\end{array}$} & \multirow{2}{*}{$\begin{array}{l}\text { Discharge } \\
\text { Systematic }+1987 \\
\text { historic flood } \\
\left(\mathrm{m}^{3} \mathrm{~s}^{-1}\right)\end{array}$} & \multirow{2}{*}{$\begin{array}{l}\text { Discharge } \\
\text { Syst. + palaeo } \\
\text { record } \\
\left(\mathrm{m}^{3} \mathrm{~s}^{-1}\right)\end{array}$} & Change \\
\hline & & & & & & & $(\%)$ \\
\hline 20 & 100 & 150 & 50 & 80 & 90 & 100 & 6 \\
\hline 10 & 200 & 250 & 21 & 150 & 190 & 200 & 3 \\
\hline 4 & 520 & 400 & -21 & 300 & 450 & 400 & -8 \\
\hline 2 & 980 & 570 & -42 & 480 & 770 & 650 & -16 \\
\hline 1 & 1750 & 760 & -56 & 700 & 1260 & 980 & -23 \\
\hline 0.5 & 3000 & 990 & -67 & 1020 & 1990 & 1400 & -30 \\
\hline 0.2 & 5800 & 1340 & -77 & 1570 & 3460 & 2130 & -38 \\
\hline 0.1 & 9340 & 1660 & -82 & 2100 & 5120 & 2840 & -45 \\
\hline
\end{tabular}

" Percentage of difference in discharge values for flood quantiles obtained for a LP3 distribution using the systematic + historic flood dataset versus the systematic + palaeoflood dataset. 
These results can be explained by the long palaeoflood record of $\sim 500$ years, that includes 19 relatively small and medium floods, and only 3 large floods $\left(>600 \mathrm{~m}^{3} \mathrm{~s}^{-1}\right.$ ). The effect of the latter on the FFA results is therefore minor. The short and discontinuous measured record (1997-2018) includes three small-medium floods and one large flood that increases the effect of low- probability floods. Nevertheless, the results of 5800 and $9340 \mathrm{~m}^{3} \mathrm{~s}^{-1}$ for the $0.2 \%$ and $0.1 \%$ annual exceedance probabilities (Table 6), are much too high and out of hydrological context for the region even for catchments that are 4-14 times larger in area (Table 1). Therefore, the FFA produces a more balanced result when the palaeoflood record combined to the gauged and historical floods, even when the gauged record is short.

\subsubsection{Nahal Rahaf}

Two palaeoflood sites, namely RAF-B and RAF-G provided discharge thresholds incrementally increasing between 400 and 1250 $\mathrm{m}^{3} \mathrm{~s}^{-1}$ over a time interval of the last 700 years (OSL age). RAF-G section (Unit 2, Fig. 8) contains a reliable radiocarbon age dated to 1667-1835 cal. CE that, together with their relative high associated perception threshold $\left(1170 \mathrm{~m}^{3} \mathrm{~s}^{-1}\right)$, provide robust arguments to assume that all flood exceeding such discharge were recorded in the stratigraphy. The frequency analysis comprises two perception thresholds (Fig. 12a): the first of $1170 \mathrm{~m}^{3} \mathrm{~s}^{-1}$, associated with RAF-G upper set over the period 1755-1986 CE, and the second of 775 $\mathrm{m}^{3} \mathrm{~s}^{-1}$ associated with the observed October 1987-flood, predating the onset of the gauge record over the period $1991-2018$.

The Log Pearson 3 distribution was found very effective to adjust to the combined palaeoflood, historic and gauged datasets with their plotting positions at the upper tail next to the fitted distribution (solid red line in Fig. 12b). An additional frequency analyses was carried out using the gauged + historical flood data. The gauged + historical flood distribution (dashed red line in Fig. 12b) resulted in higher peak flows than those of the palaeoflood + gauged floods distribution particularly for high flood quantiles, i.e. annual exceedance probabilities lower than $1 \%$. For instance, peak discharges obtained for the low annual exceedance probabilities of $0.2 \%$ and $0.1 \%$ of the systematic record + historical 1987-flood, were extremely large: 3460 and $5120 \mathrm{~m}^{3} \mathrm{~s}^{-1}$, respectively. Even if we use the largest specific peak discharge on record anywhere in the Negev and Judean Deserts for smaller basins of $10-50 \mathrm{~km}^{2}-$ about $\sim 25$ $\mathrm{m}^{3} \mathrm{~s}^{-1} \mathrm{~km}^{-1}$, and apply it to our $55 \mathrm{~km}^{2}$ basin, we obtain a peak discharge of $<1400 \mathrm{~m}^{3} \mathrm{~s}^{-1}$. We therefore, believe that the FFA results for the gauged + historic flood records are out of the regional hydrological context and should be regarded as unrealistic. The integration of long-term palaeoflood records dramatically reduced all the magnitudes for all recurrence intervals above 25 years (4 \%); the peak discharges for the low annual exceedance probabilities-2\%,1\%, $0.2 \%$ and $0.1 \%$ are $650,980,2130$ and $2840 \mathrm{~m}^{3} \mathrm{~s}^{-1}$, respectively (Table 6) - a more reasonable range. The systematic record alone (dashed gray line in Fig. 12b) provided the smallest values for all return periods (Table 6).

In the current study, in both N. Ze'elim and N. Rahaf, the difference between the analyses illustrates the effect of the long duration of the palaeoflood record over the short systematic + historic record (Table 6), which is biased towards the large floods. The incorporation of the palaeoflood data into the FFA provided significantly lower discharge estimates for the flood quantiles compared to the short systematic/historical records. This emphasizes the effect of the much longer duration of the palaeoflood records on the FFA, although the maximum peak discharges in the palaeoflood records are much larger. In contrast, in N. Rahaf the systematic record includes mainly small and medium size floods, whereas the palaeoflood record includes 3 large floods $\left(>1000 \mathrm{~m}^{3} \mathrm{~s}^{-1}\right)$ during the last 500 years which increases the effect of the low-probability floods.

In Nahal Ashalim, only a short part, 1673-1996 CE (323 years) of the extremely long palaeoflood record (7600 years), was considered relevant to the present day flood hazard assessment. This is because the entire record was assumed to include hydroclimatological changes with different flow regimes and was therefore not included in the FFA. In Nahal Heimar, the periods 1670-1996 CE (326 years) and 1810-1996 CE (186 years) provided somewhat larger peak discharge values for the shorter period, by about $27-8 \%$ for annual exceedance probabilities of $2-0.1 \%$, respectively (Greenbaum et al., 2001). The results of the present study are in line with these results.

One of the most significant contributions of palaeoflood studies to risk assessments is the significant improvement in the reliability of the FFA when comparing the results of systematic data only to the systematic + palaeoflood data. For example, in Nahal Paran (3600 $\mathrm{km}^{2}$ ) in the Negev Desert (Table 1), combining the 470-year palaeoflood record with the 50-year systematic record significantly reduced the discharges for the selected probabilities and increased the reliability dramatically, especially for low-probability floods (Greenbaum et al., 2001). In contrast, in Nahal Zin $\left(1400 \mathrm{~km}^{2}\right)$ in the Negev Desert, combining the 2000-year palaeoflood record with the 65-year systematic and historical records almost did not affect the peak discharge estimates, but the reliability of the results was dramatically improved-as represented by the decrease of about $50 \%$ in the standard errors (Greenbaum et al., 2000). Similar to our results, in the Fish River in South Africa $\left(86,600 \mathrm{~km}^{2}\right)$, for example, the recurrence intervals showed that the systematic data alone and the systematic + palaeoflood data yielded 5200 and $4415 \mathrm{~m}^{3} \mathrm{~s}^{-1}$, respectively, a decrease of $18 \%$ (Cloete et al., 2018 ).

\subsection{Comparison with conventional frequency analysis methods}

Our frequency analyses results using palaeoflood and systematic data were compared with the results of conventional frequency analyses provided by various public agencies based on systematic records only (Fig. 13). These models include (Greenbaum, 2007): (1) The Ministry of Agriculture - Soil Erosion Research Station, SERS-2 model (Garti et al., 1995) - a local detailed version of the rational formula (2) The IHS (Israel Hydrological Service) model (Meirovich et al., 1998) - a statistical regional model based on measured regional hydrological data; (3) Lavee-Natif (2004), fitting analyses of measured data from analogous basins in other parts of the Judean Desert onto ungauged Dead Sea basins. For N. Ze'elim our results were compared to all the above methods, showing that the SERS-2 and the Lavee-Natif (2004) models provide higher estimates of peak discharge relative to the present study, whereas the IHS model provides extremely low estimates (Fig. 13a). These differences are caused by the duration of the records: the effect of large floods in 

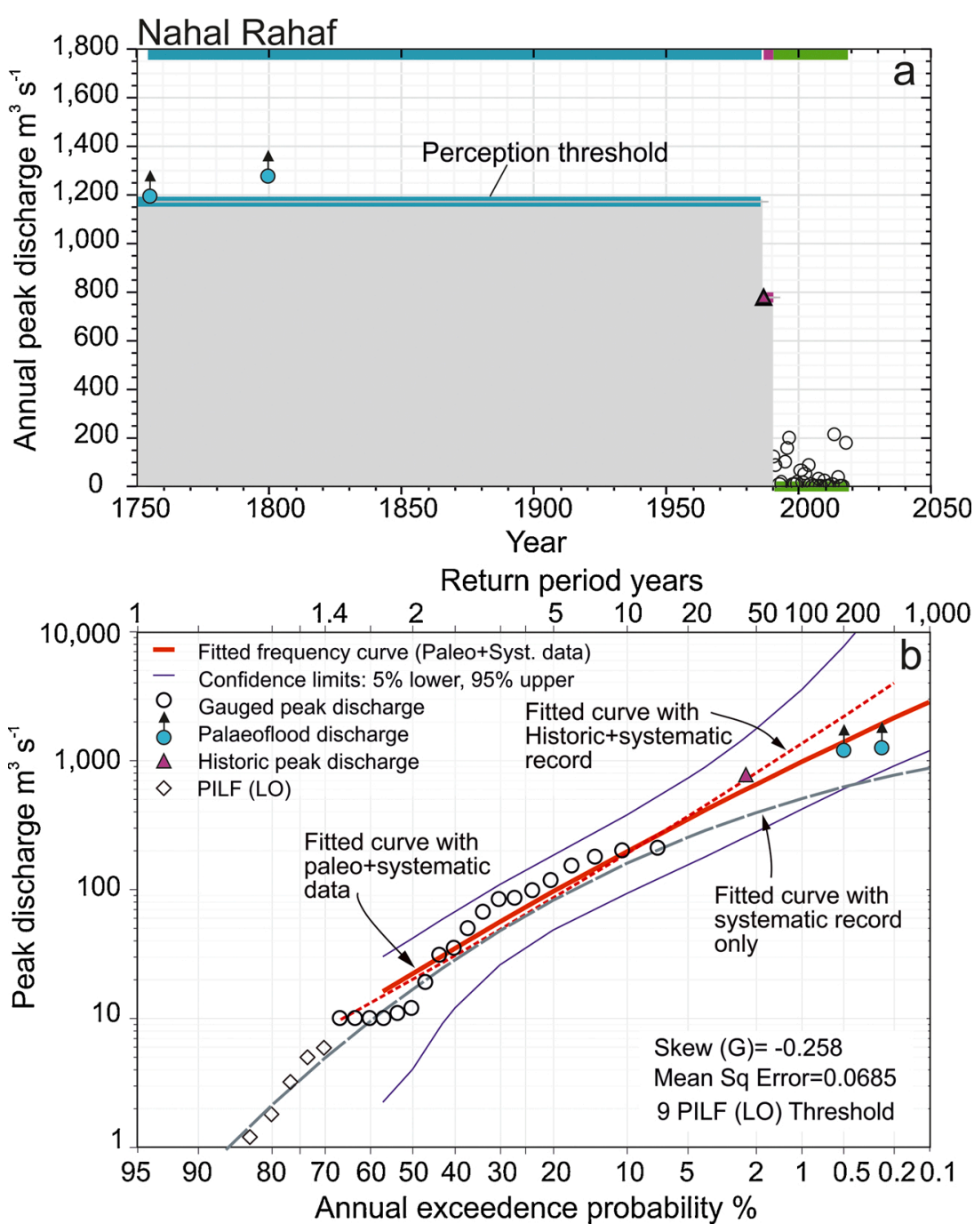

Fig. 12. Nahal Rahaf flood frequency analysis. (a) Palaeoflood and systematic discharges. Perception thresholds of 1170 and $775 \mathrm{~m}^{3} \mathrm{~s}^{-1}$, represent the maximum discharge associated with palaeo and historic floods used in the FFA. (b) Annual exceedance probability plot with the fitted LogPearson Type III (LP3) frequency curve (solid red line) using palaeoflood (green dots), historic (pink triangles) and systematic (empty dots) data. The diamond dots corresponds to the potentially influential low flood (PILFs) identify by the Multiple Grubbs-Beck Test as low outliers that can substantially distort the entire fitted distribution. The blue lines are the upper and lower confidence limits of the fitted curve. The dashed red line corresponds to the fitted LP3 distribution using the systematic and historic data only. The dashed gray line corresponds to the fitted LP3 distribution using the systematic data only. Note that in the upper tail of the distribution the fitted curve using the palaeoflood + systematic records overestimates the associated discharges, whereas the systematic record alone under-estimates the associated discharges in relation to the palaeoflood + systematic analysis.

short records is high and provides biased high values for the return periods in comparison to the long palaeoflood record which may include a number of such large floods. In N. Rahaf, we compared our results with the SERS-2 and Lavee-Natif (2004) models. Similar to our FFA for the systematic record only (Table 6), other FFAs of the systematic record using different models, provide lower values for different return periods in comparison to the paleoflood + systematic records (Fig. 13b). The much higher estimates of the combined records are related to the paleoflood population which is composed of large floods including three floods $>1000 \mathrm{~m}^{3} \mathrm{~s}^{-1}$. The different results of the various models demonstrate the significant impact of using different models for the frequency estimates, especially when the hydrological records are short and incomplete. Longer records may reduce this effect. The extended palaeoflood records fill this gap, which improves the results and enhances the reliability of the frequency analysis (Greenbaum, 2007).

Lavee-Natif (2004) estimated the maximum peak discharges for the Judean desert streams at $1000 \mathrm{~m}^{3} \mathrm{~s}^{-1}$ for N. Ze'elim, which is similar to our results $\left(900 \mathrm{~m}^{3} \mathrm{~s}^{-1}\right)$, and $700 \mathrm{~m}^{3} \mathrm{~s}^{-1}$ for $\mathrm{N}$. Rahaf compared to $1250 \mathrm{~m}^{3} \mathrm{~s}^{-1}$ in the present study. 

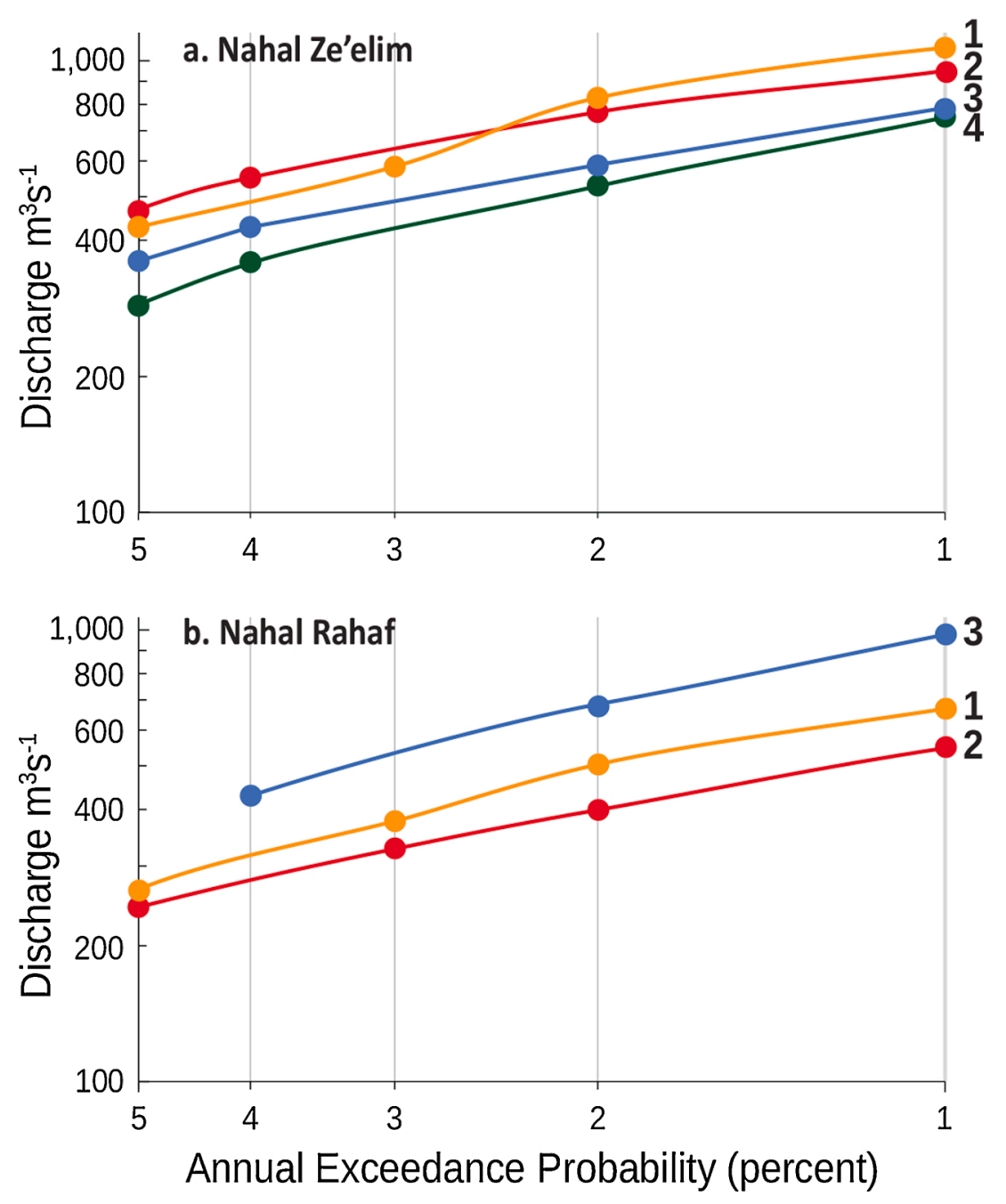

Fig. 13. Conventional and palaeoflood frequency analyses for: (A) Nahal Ze'elim: 1) SERS-2 - Soil Erosion Research Station Model, Ministry of Agriculture (Garti et al., 1995); 2) Lavee-Natif (2004); 3) current study; 4) IHS (Israel Hydrological Service) Model (Meirovich et al., 1998). Note that the present palaeoflood study provides lower discharge values for various probabilities for all the models (except no. 4) based on the systematic record only. (B) Nahal Rahaf: 1) SERS-2 model; 2) Lavee-Natif (2004); 3) current study. Note that the present palaeoflood study (line 3) provides higher discharge values for the various probabilities due to the palaeoflood population which includes larger floods including three extreme floods $\left(>1000 \mathrm{~m}^{3} \mathrm{~s}^{-1}\right)$. Note that the difference between the 100-year flood peak discharge estimates of the various models exceed $145 \%$ and $135 \%$ in $\mathrm{N}$. Ze'elim and N. Rahaf, respectively.

\section{Conclusions}

The palaeohydrological approach, in which a large number of sites are studied, was applied in this study and enabled the reconstruction of significant flood records for two steep mountainous bedrock canyons in the southern Judean Desert.

The palaeoflood record for the N. Ze'elim stream provided evidence of 18 floods with peak discharges of $220-900 \mathrm{~m}^{3} \mathrm{~s}^{-1}$ for a period of about 500 years. The largest flood of $900 \mathrm{~m}^{3} \mathrm{~s}^{-1}$, radiocarbon dated to 1980-1982 CE, and using Log-Pearson 3 distribution, attributed a recurrence interval of $<50$ years, based on the systematic record only, and 150-200 years based on the combined systematic and palaeoflood records. For N. Rahaf, the palaeoflood record includes 13 floods, with peak discharges of $170-1250 \mathrm{~m}^{3} \mathrm{~s}^{-1}$ and three, very large floods exceeding $1100 \mathrm{~m}^{3} \mathrm{~s}^{-1}$. The radiocarbon ages of these floods are around 1667-1941 CE. These floods sediments, were deposited in a rock shelter (RAF-G), 7.3 m above the channel bed, which was found to overlie an Upper Palaeolithic archaeological site dated by radiocarbon to $\sim 30,000$ years BP. For the FFA, only the data of the last 700 years was analyzed due to the large time gap between the older and the younger populations, and in order to make it more relevant to present hazard assessment. Using Log Pearson 3 distribution, the largest flood, $1250 \mathrm{~m}^{3} \mathrm{~s}^{-1}$, attributed a recurrence interval of 500 years for the combined systematic and palaeoflood records.

In both streams, the FFA for the systematic + historic data only, overestimated the frequencies of the large floods, most probably due to their short and discontinuous records. This was also true for other conventional frequency analyses applied by other agencies 
based on the available systematic record alone. The population of the palaeofloods in N. Rahaf with the three extreme floods ( $>1000$ $\mathrm{m}^{3} \mathrm{~s}^{-1}$ ) finally provides higher discharges for the various low probabilities. The palaeoflood data extends the record to several hundred years, reducing the peak discharge values for different return periods and significantly enhancing FFA reliability.

\section{Author statement}

Rami Zituni: conceptualization, data collection, processing, analysis, methodology, hydraulic software, writing

Noam Greenbaum: conceptualization, methodology, processing, writing

Gerardo Benito: frequency analysis

Naomi Porat: OSL

\section{Declaration of Competing Interest}

The authors declare that they have no known competing financial interests or personal relationships that could have appeared to influence the work reported in this paper.

\section{Acknowledgments}

The authors thank Omri Ilan, Inna Burstein-Zituni and Liran Nahum for assisting in the fieldwork; Yael Jacobi of the Geological Survey of Israel for helping with the OSL samples, and Noga Yoselevich of the Cartography Laboratory at the Department of Geography, University of Haifa for drawing the figures. The study was funded by the Israel Water Authority, Grant No. 4501284533.

\section{Appendix A. Supplementary data}

Supplementary material related to this article can be found, in the online version, at doi:https://doi.org/10.1016/j.ejrh.2021. 100886.

\section{References}

Amit, R., Gerson, R., 1986. The evolution of Holocene reg (gravelly) soils in deserts - an example from the Dead Sea region. Catena 13, 59-79.

Armon, M., Dente, E., Smith, J.A., Enzel, Y., Morin, E., 2018. Synoptic-scale control over modern rainfall and flood patterns in the Levant drylands with implications for past climates. J. Hydrometeorol. 19, 1077-1096. https://doi.org/10.1175/JHM-D-18-0013.1.

Baker, V.R., 1987. Paleoflood hydrology and extraordinary flood events. J. Hydrol. 96, 79-99.

Baker, V.R., Kochel, R.C., 1988. Flood sedimentation in bedrock fluvial systems. In: Baker, V.R., Kochel, R.C., Patton, P.C. (Eds.), Flood Geomorphology. John Wiley and Sons, New York, USA, pp. 123-137.

Barzilai, O., Aldjam, E., Shemer, M., Zituni, R., Greenbaum, N., Boaretto, E., Marom, N., 2020. The early upper paleolithic in south Judean Desert, Israel: preliminary excavation results from Nahal Rahaf 2 rock shelter. Antiquity.

Benito, G., Thorndycraft, V.R., 2005. Palaeoflood hydrology and its role in applied hydrological sciences. Palaeofloods, Hist. data Clim. Var. Appl. flood risk Assess. 313, 3-15. https://doi.org/10.1016/j.jhydrol.2005.02.002.

Benito, G., Sanchez-Moya, Y., Sopena, A., 2003a. Sedimentology of high-stage flood deposits of the Tagus River, Central Spain. Sediment. Geol. 157, 107-132. https:// doi.org/10.1016/S0037-0738(02)00196-3.

Benito, G., Sopena, A., Sanchez-Moya, Y., Machado, M.J., Perez-Gonzalez, A., 2003b. Palaeoflood record of the Tagus River (Central Spain) during the late pleistocene and holocene. Quat. Sci. Rev. 22, 1737-1756. https://doi.org/10.1016/S0277-3791(03)00133-1.

Benito, G., Thorndycraft, V.R., Rico, M.T., Sanchez-Moya, Y., Sopena, A., Botero, B.A., Machado, M.J., Davis, M., Perez-Gonzalez, A., 2011. Hydrological response of a dryland ephemeral river to southern African climatic variability during the last millennium. Quat. Res. 75, 471-482. https://doi.org/10.1016/j. yqres.2011.01.004.

Benito, G., Harden, T.M., O'Connor, J., 2020. Quantitative paleoflood hydrology. In: Wohl, E.E. (Ed.), Reference Module in Earth Systems and Environmental Sciences. Elsevier. https://doi.org/10.1016/B978-0-12-409548-9.12495-9.

Bull, L.J., Kirkby, M., 2002. Dryland rivers characteristics and concepts. In: Bull, L.J., Kirkby, M. (Eds.), Dryland Rivers: Hydrology and Geomorphology of Semiarid Channels. John Wiley, Chichester, pp. 3-14.

Chow, V.T., 1973. Open-Channel Hydraulics. Chap. 16-4. McGraw-Hill Book Company, pp. $444-448$.

Cloete, G., Benito, G., Grodek, T., Porat, N., Enzel, Y., 2018. Analyses of the magnitude and frequency of a 400 -year flood record in the Fish River Basin, Namibia. Geomorphology 320, 1-17. https://doi.org/10.1016/j.geomorph.2018.07.025.

Cohen, H., Laronne, J.B., 2005. High rates of sediment transport by flashfloods in the Southern Judean Desert, Israel. Hydrol. Process. 19, 1687-1702. https://doi. org/10.1002/hyp.5630.

Cohn, T.A., Lane, W.L., Baier, W.G., 1997. An algorithm for computing moments-based flood quantile estimates when historical flood information is available. Water Resour. Res. 33, 2089-2096. https://doi.org/10.1029/97wr01640, 1997.

Cohn, T.A., England, J.F., Berenbrock, C.E., Mason, R.R., Stedinger, J.R., Lamontagne, J.R., 2013. A generalized Grubbs-Beck test statistic for detecting multiple potentially influential low outliers in flood series. Water Resour. Res. 49, 5047-5058. https://doi.org/10.1002/wrcr.20392, 2013.

Dayan, U., Morin, E., 2006. Flash flood-producing rainstorms over the Dead Sea; a review. New Front. Dead Sea Paleoenviron. Res. 401, 53-62. https://doi.org/ $10.1130 / 2006.2401(04)$.

Ely, L.L., Baker, V.R., 1985. Reconstructing paleoflood hydrology with slackwater deposits; Verde River, Arizona. Bull. Geogr. Phys. Geogr. Ser. 6, 103-126.

Ely, L.L., Enzel, Y., Baker, V.R., Cayan, R., 1993. A 5000-year record of extreme floods and climate change in the southwestern United States. Science 262 , 410-412.

England Jr., J.F., Cohn, T.A., Faber, B.A., et al., 2019. Guidelines for Determining Flood Flow Frequency-Bulletin 17C, 4-B5, Reston, VA.

Enzel, Y., Ely, P.K., House, P.K., Baker, V.R., Webb, R.H., 1993. Paleoflood evidence for a natural upper bound to flood magnitudes in the Colorado river basin. Water Resour. Res. 29, 2287-2297.

Enzel, Y., Ely, L.L., Martinez-Goytre, J., Vivian, R.G., 1994. Paleofloods and a dam-failure flood on the Virgin River, Utah and Arizona. J. Hydrol. 153, 291-315. 
Faershtein, G., Porat, N., Avni, Y., Matmon, A., 2016. Aggradation-incision transition in arid environments at the end of the Pleistocene: an example from the Negev Highlands, southern Israel. Geomorphology 253, 289-304. https://doi.org/10.1016/j.geomorph.2015.10.017.

Farquharson, F.A.K., Meigh, J.R., Sutcliffe, J.V., 1992. Regional flood frequency analysis in arid and semi-arid areas. J. Hydrol. 138, 487-501. https://doi.org/ 10.1016/0022-1694(92)90132-F.

Federal Highway Administration (FHWA), 2012. Hydraulic Design of Highway Culverts, 3rd edition. Federal Highway Administration, U.S. Dept. of Transportation. Publication no. FHWA HIF-12-026, 2012

Flynn, K.M., Kirby, W.H., Hummel, P.R., 2006. User's Manual for Program PeakFQ Annual Flood-Frequency Analysis Using Bulletin 17B Guidelines. U.S. Geological Survey, p. 42.

Frances, F., 2004. Flood frequency analysis using systematic and non-systematic information. In: Benito, G., Thorndycraft, V.R. (Eds.), Systematic, Paleoflood and Historical Data for the Improvement of Flood Risk Estimation: Methodological Guidelines. CSIS, Madrid, pp. 55-70.

Frances, F., Salas, J.D., Boes, D.C., 1994. Flood frequency analysis with systematic and historical or paleoflood data based on the two-parameter general extreme value models. Water Resour. Res. 30 (6), 1653-1664.

Garti, R., Getker, M., Arbel, S., 1995. Model SERS-2 for peak discharges and annual runoff volumes estimates for drainage basins in Israel. Rep. OL-22. Soil Erosion and Research Station, Ministry of Agriculture, Israel (in Hebrew).

Greenbaum, N., 2007. Assessment of dam failure flood and a natural, high-magnitude flood in a hyperarid region using paleoflood hydrology, Nahal Ashalim catchment, Dead Sea, Israel. Water Resour. Res. 43 https://doi.org/10.1029/2006WR004956.

Greenbaum, N., Margalit, A., Schick, A.P., Sharon, D., Baker, V.R., 1998. A high magnitude storm and flood in a hyperarid catchment, Nahal Zin, Negev Desert, Israel. Hydrol. Process. 12, 1-23.

Greenbaum, N., Enzel, Y., Schick, A.P., 2001. Magnitude and frequency of paleofloods and historical floods in the Arava basin, Negev Desert, Israel. Isr. J. Earth Sci. 50, 159-186. https://doi.org/10.1092/N5VU-FU5F-QNWC-UDCK.

Greenbaum, N., Ben-Zvi, A., Haviv, I., Enzel, Y., 2006. The hydrology and paleohydrology of the Dead Sea tributaries. In: Enzel, Y., Agnon, A., Stein, M. (Eds.), New Frontiers in Dead Sea Paleoenvironmental Research. The Geological Society of America, Colorado, USA, pp. 63-93.

Greenbaum, N., Schwartz, U., Bergman, N., 2010. Extreme floods and short-term hydroclimatological fluctuations in the hyper-arid Dead Sea region, Israel. Glob. Planet. Change 70, 125-137. https://doi.org/10.1016/j.gloplacha.2009.11.013.

Greenbaum, N., Harden, T.M., Baker, V.R., Weisheit, J., Cline, M.L., Porat, N., Halevi, R., Dohrenwend, J., 2014a. A 2000 year natural record of magnitudes and frequencies for the largest Upper Colorado River floods near Moab, Utah. Water Resour. Res. 50, 5249-5269. https://doi.org/10.1002/2013WR014835.

Greenbaum, N., Schick, A.P., Baker, V.R., 2000. The palaeoflood record of a hyperarid catchment, Nahal Zin, Negev Desert, Israel. Earth Surf. Process. Landf. 25 (9), 951-971.

Greenbaum, N., Schwartz, U., Benito, G., Porat, N., Cloete, G.C., Enzel, Y., 2014b. Paleohydrology of extraordinary floods along the Swakop River at the margin of the Namib Desert and their paleoclimate implications. Quat. Sci. Rev. 103, 153-169. https://doi.org/10.1016/j.quascirev.2014.08.021.

Grodek, T., Benito, G., Botero, B.A., Jacoby, Y., Porat, N., Haviv, I., Cloete, G., Enzel, Y., 2013. The last millennium largest floods in the hyperarid Kuiseb River basin, Namib Desert. J. Quat. Sci. 28, 258-270. https://doi.org/10.1002/jqs.2618.

Harden, T.M., O'Connor, J.E., Driscoll, D.G., Stamm, J.F., 2011. Flood-frequency analyses from paleoflood Investigations for Spring, Rapid, Boxelder, and Elk Creeks, Black Hills, Western South Dakota, Scientific Investigations Report. U. S. Geological Survey, Reston, VA, United States, Reston, Virginia, p. 136.

Hu, G., Huang, C.C., Zhou, Y., Pang, J., Zha, X., Guo, Y., Zhang, Y., Zhao, X., 2016. Extreme paleoflood events 3200-3000 a BP in the Jingyuan-Jingtai reaches of the upper Yellow River, China. Holocene 26, 790-800. https://doi.org/10.1177/0959683615618257.

Hydrological Engineering Center, 2010. HEC-RAS: Water River Analysis, Version 4.0. U.S. Army Corp. of Eng, Davis, Calif.

Israel Hydrological Service (IHS), 2018. Open Hydrological Data Files, Report. Jerusalem.

Israel National Atlas, 2011. The Hebrew University of Jerusalem, Department of Geography, Jerusalem and the Survey of Israel, Tel Aviv,139 pp.

Kahana, R., Ziv, B., Enzel, Y., Dayan, U., 2002. Synoptic climatology of major floods in the Negev Desert, Israel. Int. J. Climatol. 22, 867-882. https://doi.org/ 10.1002/joc.766.

Kale, V., Singhvi, A., Mishra, P., Banerjee, D., 2000. Sedimentary records and luminescence chronology of Late Holocene palaeofloods in the Luni River, Thar Desert, northwest India. Catena 40 (4), 337-358.

Knippertz, P., 2005. Tropical-extratropical interactions associated with an Atlantic tropical plume and subtropical jet streak. Mon. Weather Rev. 133, 2759-2776. https://doi.org/10.1175/MWR2999.1.

Kochel, R.C., Baker, V.R., 1982. Paleoflood hydrology. Science 215, 353-361.

Kochel, R.C., Baker, V.R., Patton, P.C., 1982. Paleohydrology of Southwestern Texas. Water Resour. Res. 18 (4), 1165-1183.

Lavee-Natif, 2004. Stream Network Study in the Dead Sea Drainage Area. Haifa, Israel (in Hebrew).

Levran, D., 2018. Landscape Evolution of the Judean Desert; the Ze'elim Basin Case Study. Ben Gurion University of the Negev, Be'er Sheva (Master's thesis). (in Hebrew).

Liu, T., Greenbaum, N., Baker, V.R., Ji, L., Onken, J., Weisheit, J., Porat, N., Rittenour, T., 2020a. Paleoflood hydrology on the lower Green River, upper Colorado River Basin, USA: an example of a naturalist approach to flood-risk analysis. J. Hydrol. 580 https://doi.org/10.1016/j.jhydrol.2019.124337.

Liu, T., Ji, L., Baker, V.R., Harden, T.M., Cline, M.L., 2020b. Holocene extreme paleofloods and their climatological context, Upper Colorado River Basin, USA. Prog. Phys. Geogr. Earth Environ. https://doi.org/10.1177/0309133320904038, 0309133320904038.

Medialdea, A., Thomsen, K.J., Murray, A.S., Benito, G., 2014. Reliability of equivalent-dose determination and age-models in the OSL dating of historical and modern palaeoflood sediments. Quat. Geochronol. 22, 11-24. https://doi.org/10.1016/j.quageo.2014.01.004.

Meirovich, L., Ben-Zvi, I., Shentsis, I., Yanovich, E., 1998. Frequency and magnitude of runoff events in the arid Negev of Israel. J. Hydrol. 207, 204-219.

Metzger, A., Marra, F., Smith, J.A., Morin, E., 2020. Flood frequency estimation and uncertainty in arid/semi-arid regions. J. Hydrol. 590, 125254.

Murray, A.S., Wintle, A.G., 2000. Luminescence dating of quartz using an improved single-aliquot regenerative-dose protocol. Radiat. Meas. 32, 57-73. https://doi. org/10.1016/S1350-4487(99)00253-X.

Nir, D., 1989. The Judean desert, in: Geomorphology of Israel. Akademon, Jerusalem, pp. 88-129 (in Hebrew).

O'Connor, J.E., 1994. A 4500-year record of large floods on the Colorado River in the Grand Canyon, Arizona. J. Geol. 102, 1-9. https://doi.org/10.1086/629644.

O'Connor, J.E., Webb, R.H., 1988. Hydraulic modeling for palaeoflood analysis. In: Baker, V.R., Kochel, R.C., Patton, P.C. (Eds.), Flood Geomorphology. John Wiley and Sons, New York, pp. 393-403.

Patton, P.C., Baker, V.R., Kochel, R.C., et al., 1979. Slack water deposits: A geomorphic technique for the interpretation of fluvial paleohydrology. In: Rhodes, D., Williams, G. (Eds.), Slack water deposits: A geomorphic technique for the interpretation of fluvial paleohydrology. Kendall/Hunt, Dubuque, Iowa, pp. 225-253.

Patton, P.C., Pickup, G., Price, D.M., 1993. Holocene paleofloods of the Ross River, central Australia. Quat. Res. 40, 201-212. https://doi.org/10.1006/ qres.1993.1072.

Polak, S., 1988. Maximal Peak Discharges After the Rainstorm of the 17-18.10.1987. Isr. Hydrol. Serv. Rep. Hydro/2/ 1988 (in Hebrew).

Porat, N., Faerstein, G., Medialdea, A., Murray, A.S., 2015. Re-examination of common extraction and purification methods of quartz and feldspar for luminescence dating. Anc. TL 33, 22-30.

Ramsey, C.B., 2017. Methods for summarizing radiocarbon datasets. Radiocarbon 59, 1809-1833. https://doi.org/10.1017/RDC.2017.108.

Reimer, P.J., 2020. Composition and consequences of the IntCal 20 radiocarbon calibration curve. Quat. Res. 96, $22-27$.

Schick, A.P., 1988. Hydrologic aspects of floods in extreme arid environments. In: Baker, V.R., Kochel, R.C., Patton, P.C. (Eds.), Flood Geomorphology. John Wiley and Sons, New York, pp. 189-204.

Sheffer, N.A., Enzel, Y., Benito, G., Grodek, T., Poart, N., Lang, M., Naulet, R., Coeur, D., 2003. Paleofloods and historical floods of the Ardeche River, France. Water Resour. Res. 39, ESG71-ESG713. https://doi.org/10.1029/2003WR002468.

Shentsis, I., Ben-Zvi, A., Golts, S., 1997. A physically-related regional model for extreme discharges in Israel. Hydrol. Sci. J. Des Sci. Hydrol. 42 , 391-404. 
Shentsis, I., Laronne, J.B., Alpert, P., 2012. Red sea trough flood events in the Negev, Israel (1964-2007). Hydrol. Sci. J. Des Sci. Hydrol. 57, 42-51. https://doi.org/ $10.1080 / 02626667.2011 .636922$.

Stedinger, J.R., Baker, V.R., 1987. Surface water hydrology: historical and paleoflood information. Rev. Geophys. 25, $119-124$.

Stedinger, J.R., Cohn, T.A., 1986. Flood frequency analysis with historical and paleoflood information. Water Resour. Res. 22, 785-793. https://doi.org/10.1029/ WR022i005p00785.

Survey of Israel, 2021 - https://www.govmap.gov.il/.

UNEP, 2011. Global Drylands: a UN System-wide Response. Accessed on 24/3/2021. United Nations Environment Management Group, p. 132. https://www.unepwcmc.org/system/dataset_file_fields/files/000/000/091/original/Global-Drylands-FINAL-LR.pdf?1398440625.

Veilleux, A.G., Cohn, T.A., Flynn, K.M., Mason Jr., R.R., Hummel, P.R., 2014. Estimating Magnitude and Frequency of Floods Using the PeakFQ 7.0 Program: U.S. Geological Survey Fact Sheet 2013-3108, p. 2. https://doi.org/10.3133/fs20133108.

Webb, R.H., O'Connor, J.E., Baker, V.R., 1988. Paleohydrological reconstruction of floods frequency on the Escalante River, South-Central, Utah. In: Baker, V.R., Kochel, R.C., Patton, P.C. (Eds.), Flood Geomorphology. John Wiley and Sons, New York, pp. 403-420.

Webb, R.H., Blainey, J.B., Hyndman, D.W., 2002. Paleoflood hydrology of the Paria river Southern Utah and Northern Arizona, USA. In: House, P.K., Webb, R.H., Baker, V.R., Levish, D.R. (Eds.), Ancient Floods, Modern Hazards: Principles and Applications of Paleoflood Hydrology. American union water science and application, Washington, DC, USA, pp. 295-310.

Zaman, M.A., Rahman, A., Haddad, K., 2012. Regional flood frequency analysis in arid regions: a case study for Australia. J. Hydrol. 475, 74-83. https://doi.org/ 10.1016/j.jhydrol.2012.08.054. 